Volume 116

Issue 2 Dickinson Law Review - Volume 116,

2011-2012

$10-1-2011$

\title{
Improving the Culture of Ethical Behavior in the Financial Sector: Time to Expressly Provide for Private Enforcement Against Aiders and Abettors of Securities Fraud
}

Mark Klock

Follow this and additional works at: https://ideas.dickinsonlaw.psu.edu/dlra

\section{Recommended Citation}

Mark Klock, Improving the Culture of Ethical Behavior in the Financial Sector: Time to Expressly Provide for Private Enforcement Against Aiders and Abettors of Securities Fraud, 116 DICK. L. REV. 437 (2011). Available at: https://ideas.dickinsonlaw.psu.edu/dlra/vol116/iss2/5

This Article is brought to you for free and open access by the Law Reviews at Dickinson Law IDEAS. It has been accepted for inclusion in Dickinson Law Review by an authorized editor of Dickinson Law IDEAS. For more information, please contactlja10@psu.edu. 


\title{
Improving the Culture of Ethical Behavior in the Financial Sector: Time to Expressly Provide for Private Enforcement Against Aiders and Abettors of Securities Fraud
}

\author{
Mark Klock*
}

\begin{abstract}
$\underline{\text { Abstract }}$
Financial markets do not function well when fraud is pervasive. It has been well documented that financial fraud has increased following changes in securities law that occurred in the 1990's. Also around September of 2009, the investigations into the SEC examinations of Bernard Madoff Investment Securities, LLC were completed and released to the public. The simple facts reveal an alarming level of incompetence and lack of financial literacy on the part of the guardians of the integrity of our financial markets. I suggest two important tools for addressing these problems. One is to supplement enforcement of anti-fraud rules with more private attorney generals by expressly creating a private right of action for aiding and abetting violations of securities laws. This will foster a stronger culture of integrity and ethical conduct in the auditing profession. An additional tool is to increase financial literacy in our law schools which supply the regulators of our markets.
\end{abstract}

* B.A., The Pennsylvania State University, 1978; Ph.D. in Economics, Boston College, 1983; J.D. (with honors), University of Maryland, 1988; admitted to the Maryland Bar, 1988; admitted to the District of Columbia Bar, 1989; member of the Executive Board, Center for Law, Economics, and Finance, The George Washington University School of Law; Professor of Finance, The George Washington University School of Business, Washington, D.C. The author acknowledges financial support from the Institute for Corporate Responsibility at George Washington University. 


\section{Table of Contents}

I. INTRODUCTION . 438

II. THE RISE AND FALl of AIDING AND ABETTING DOCTRINE IN SECURITIES FraUd

A. Legal Authority for Aiding and Abetting Liability in Federal Securities Law....

B. Policy Arguments for Aiding and Abetting Liability.................. 446

C. The Demise of Aiding and Abetting Liability.............................. 449

D. Stoneridge-Further Squashing Private Actions ........................ 453

III. THE AFTERMATH OF CENTRAL BANK-AN EPIDEMIC OF FINANCIAL SCANDALS

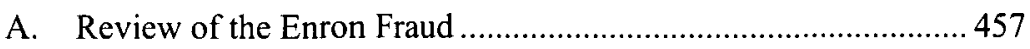

B. Market Efficiency and Fraud-on-the-Market Reliance ............... 459

C. Participating in Fraud Establishes a Duty ................................. 462

D. Removing Liability Removes Incentives for Ethical Behavior.... 464

IV. A Caveat on Behavioralists' Proposals for Paternalistic REGULATION

A. Market Volatility Does Not Imply that Markets are Irrational or Inefficient.

B. Paternalistic Protection Creates Moral Hazard .............................4 476

V. THE MAdOFF SCANDAL EXPOSES LIMITATIONS OF REgUlatorS ........478

VI. OPTIMAL REgULATION SHOULD INCENTIVIZE ETHICS......................... 485

A. A Problem with Paternalistic Regulators-Inability to Define the Public Good................................................................. 485

B. Incentivizing Ethics Works Better than Micro-Management....... 488

VII. CONCLUSION

\section{INTRODUCTION}

From the shocking surprise decision in the 1994 case of Central Bank of Denver v. First Interstate Bank of Denver, ${ }^{1}$ through the somewhat predictable outcome but poorly reasoned 2008 decision in Stoneridge Investment Partners, LLC v. Scientific-Atlanta, Inc., ${ }^{2}$ the latter-day Supreme Court has systematically reduced the ability of defrauded investors to recover their losses from culpable participants who did not sell securities or communicate with investors. ${ }^{3}$ With the recent revelations that the Securities and Exchange Commission's Office

1. Cent. Bank of Denver, N.A. v. First Interstate Bank of Denver, N.A., 511 U.S. 164 (1994).

2. Stoneridge Inv. Partners, LLC v. Scientific-Atlanta, Inc., 552 U.S. 148 (2008).

3. See id. at 178-80 (Stevens, J., dissenting) ("Until Central Bank, the federal courts continued to enforce a broad implied cause of action for the violation of statutes enacted in 1933 and 1934 for the protection of investors. . . Today's decision simply cuts back further on Congress' intended remedy."). 
of Compliance, Investigations, and Examinations has not performed its responsibilities to the public with any diligence, as exemplified by Bernard Madoff and other scandals, ${ }^{4}$ the time is ripe for Congressional action to provide more express remedies in private actions based on securities fraud. $^{5}$ In this article, I will review the history of aiding and abetting liability for secondary participants under the federal securities laws, ${ }^{6}$ and review the public record of the SEC's incompetence in detecting Ponzi schemes ${ }^{7}$ and unwillingness to pursue aiders of securities fraud violations. ${ }^{8} \quad$ I argue that these factors working together have fostered a culture of less than ethical conduct on the part of accountants, auditors, corporations, and financial intermediaries which contributed to the recent financial crisis. ${ }^{9}$ Legislative changes to expressly promote

4. See generally Mark Klock, Lessons Learned from Bernard Madoff: Why We Should Partially Privatize the Barney Fifes at the SEC, 42 ARIZ. ST. L.J. 783, 784-835 (2010) (documenting the mishandling of Madoff by SEC staff and noting that the case was not an isolated incident); Robert J. Rhee, The Madoff Scandal, Market Regulatory Failure and the Business Education of Lawyers, 35 J. CORP. L. 363, 363-81 (2009) (documenting SEC malfeasance in the Madoff fraud).

5. See Where Were the Watchdogs? Financial Crises and Breakdown of Financial Governance, Statement before Homeland Security and Governmental Affairs Committee, 111th Cong. 355 (Jan. 21, 2009) (statement of Sen. Carl Levin, Chairman, Perm. Subcomm. on Investigations) ("Legislation reversing Stoneridge would restore civil liability for aiders and abettors of corporate fraud.").

6. See generally William H. Kuehnle, Secondary Liability Under The Federal Securities Laws-Aiding and Abetting, Conspiracy, Controlling Person, and Agency: Common-Law Principles and The Statutory Scheme, 14 J. CoRP. L. 313, 313-76 (1989) (providing a comprehensive history of aiding and abetting and other forms of secondary liability under federal securities laws); Robert A. Prentice, Stoneridge, Securities Frand Litigation, and the Supreme Court, 45 AM. BUS. L.J. 611, 619-83 (2008) (discussing historical development of liability for participation in securities fraud).

7. See generally, U.S. SECURITIES AND EXCHANGE COMMISSION OFFICE OF INSPECTOR GENERAL, REPORT NO. 509, INVESTIGATION OF FAILURE OF THE SEC TO UNCOVER BERNARD MAdOFF's PONZI SCHEME (Aug. 31, 2009) [hereinafter OIG, INVESTIGATION OF MADOFF], http://www.sec.gov/news/studies/2009/oig-509.pdf (last visited Jan. 11, 2011) (documenting the public evidence of malfeasance by the SEC staff regarding Madoff's massive fraud).

8. See Brief for the United States as Amicus Curiae Supporting Affirmance, Stoneridge Inv. Partners, LLC v. Scientific-Atlanta, Inc., 522 U.S. 148 (2008) No. 0643), 2007 WL 2329639 (arguing for the defendants and against the plaintiffs seeking recovery from participants in securities fraud); Brief for Former SEC Commissioners and Officials and Law and Finance Professors as Amicus Curiae Supporting Affirmance, Stoneridge, 522 U.S. 148 (No. 06-43), 2007 WL 2329638 (listing sixteen former SEC officials (three chairs, eleven commissioners, and two general counsel) arguing for the defendants and against the plaintiffs seeking recovery from participants in securities fraud).

9. Cf. John C. Coffee, Jr., What Caused Enron? A Capsule Social and Economic History of the 1990s, 89 CORNELL L. REV. 269, 287-92 (2004) (suggesting that the increase in financial scandals based on financial reporting irregularities can be attributed to a shift in the cost-benefit analysis of incentives due to a decreased litigation threat and an increase in profitability of aggressive earnings reporting). 
more aggressive private enforcement of our securities laws would necessarily change the culture and promote more ethical behavior in our financial markets. ${ }^{10}$

Historically, securities regulation in the United States adopted a non-paternalistic philosophy of requiring full and fair disclosure enforced in large part with broad civil liability for those who perpetrated fraud in the public market for securities. ${ }^{11}$ Certain devices were created to provide powerful incentives to issuers. ${ }^{12}$ For example, strict liability provisions relieve plaintiffs from the burden of proving loss causation. ${ }^{13}$ Given this strong anti-fraud environment, public markets flourished and contributed to low capital costs, capital investment, economic prosperity, and victory in the Cold War. ${ }^{14}$ In this environment, the application of aiding and abetting doctrine to the securities laws seemed to be a natural development. ${ }^{15}$ In that regime, accountants, auditors, and bankers rationally feared liability for assisting securities fraud and therefore had powerful incentives to act with high ethical standards. ${ }^{16}$ In the new environment in which the aiding and abetting doctrine has been rendered toothless, unethical conduct by key players in the financial markets has been the predictable result. ${ }^{17}$

10. See Mark Klock, Two Possible Answers to the Enron Experience: Will It Be Regulation of Fortune Tellers or Rebirth of Secondary Liability?, 28 J. CORP. L. 69, 10406 (2002) (arguing that legislation to expressly private liability for aiding and abetting securities fraud is needed to improve ethical standards in financial reporting).

11. See, e.g., MARC I. SteInBERG, SeCurities Regulation 3 (4th ed. 2004) (noting that the philosophy of the federal government in securities regulation has been designed to provide investors with accurate and complete information).

12. For example, the strict liability for those who offer or sell a security using a false or misleading communication. Securities Act of 1933 § 12, 15 U.S.C. $\S 771$ (2006).

13. LaRry D. Soderquist \& Theresa A. Gabaldon, Securities Regulation 253 (5th ed. 2003) ("Proof of causation is not a requirement for recovery. ...").

14. See Mark Klock, What Will It Take to Label Participation in a Deceptive Scheme to Defraud Buyers of Securities a Violation of Section 10(b)? The Disastrous Result and Reasoning of Stoneridge, 58 U. KAN. L. REV. 309, 353 (2010) (describing the importance of well-functioning financial markets, but noting flourishing markets require an antifraud environment).

15. See generally Prentice, supra note 6, at 619-63 (analyzing the common law of fraud and its incorporation into the Securities Exchange Act).

16. See Coffee, supra note 9, at 287-90 (describing the regime shift from one where auditors faced frequent class-action litigation and exposure to large judgments to one in which they were insulated from large legal exposure).

17. Cf. Prentice, supra note 6 , at 682 (pointing out that a majority of the Supreme Court is no longer opposed to fraud); Charles W. Murdock, Corporate Corruption and the Complicity of Congress and the Supreme Court-The Tortuous Path from Central Bank to Stoneridge Investment Partners, 6 BERKELEY Bus. L.J. 131, 197 (2009) ("What is clear is the complicity of the Supreme Court because it was well aware of the fraudulent activity and nonetheless insulated defendants from liability. It is strong language to suggest that the Supreme Court is complicit in furthering fraud."). 


\section{THE RISE AND FALL OF AIDING AND ABETTING DOCTRINE IN SECURITIES FRAUD}

\section{A. Legal Authority for Aiding and Abetting Liability in Federal Securities Law}

The principle that one could be held liable for aiding and abetting a violation of federal securities law evolved as a straightforward application of a doctrine used in criminal, agency, and tort law. ${ }^{18}$ Under these bodies of law, an individual can be held jointly liable as a primary violator of a duty if he assists or supports the violation of a duty actually committed by the primary violator, or is liable for the violation through a relationship (such as an employment contract or parental control) with the violator. ${ }^{19}$ So, for example, if one assists in preparing false financial statements by engaging in bogus business transactions and falsifying documents to provide an appearance of legitimacy to the transactions, that individual could have been held liable twenty years ago for securities fraud even if he was not present and did not participate in the sale of the securities. ${ }^{20}$ Today such behavior cannot be subject to private actions, $^{21}$ so the incentives to act ethically are greatly reduced and the result of the changed incentives is an obvious increase in unethical behavior. $^{22}$

Aiding and abetting liability for fraud was part of the common-law environment prior to enactment of the securities laws, which sought to expand investor protection. ${ }^{23}$ Given the broad remedial intent of the

18. See Kuehnle, supra note 6 , at $314 \mathrm{n} .1$ (stating that secondary civil liability under the federal securities laws is derived from agency and tort law and to a lesser extent criminal law).

19. See William C. Humphreys, Jr., Aiding and Abetting Liability of Accountants in Securities Fraud Cases, 17 SEC. REG. L.J. 375, 379-80 (1990) (describing the elements of aiding and abetting liability).

20. See, e.g., SEC v. Wash. Cnty. Util. Dist., 676 F.2d 218, 223 (6th Cir. 1982) ("Direct contacts require neither physical presence nor face to face conversation. A person undertaking to furnish information which is misleading because of a failure to disclose a material fact is a primary participant."); SEC v. Coffey, 493 F.2d 1304, 1315 n.24 (6th Cir. 1974) ("An accountant or lawyer, for instance, who prepares a dishonest statement is a primary participant in a violation even though someone else may conduct the personal negotiations with a securities purchaser.").

21. See Stoneridge Inv. Partners, LLC v. Scientific-Atlanta, Inc., 552 U.S. 148, $160-$ 61 (2008) (holding that fraud in the transactions underlying the public statements about the securities is not actionable under $\S 10(\mathrm{~b})$ of the Securities Exchange Act).

22. See Klock, supra note 14, at 344 ("A rule that allows everything except that which is not expressly prohibited encourages excessive unethical behavior and will drive capital out of the market.").

23. See Stoneridge, 552 U.S. at 179-80 (Stevens, J., dissenting) ("Courts near in time to the enactment of the securities laws recognized that the principle in Rigsby applied to the securities laws." (citing Tex. \& Pac. Ry. Co. v. Rigsby, 241 U.S. 33, 39 (1916) for the 
securities laws to proscribe bad behavior in financial markets and promote confidence and integrity in the markets, it was quite logical to continue application of the doctrine after enactment of the ' 33 Securities Act and the ' 34 Securities Exchange Act. ${ }^{24}$ Essentially, the doctrine required the existence of a securities law violation, at least one primarily liable party, and at least one party that provided substantial assistance to a primary violator. ${ }^{25}$ The level of knowledge about the violation required varied across circuits, and in some cases interacted with the level of assistance provided. ${ }^{26}$ So a low level of assistance might require actual knowledge and a high level of assistance might merely require a reckless disregard. ${ }^{27}$ In some circuits, the knowledge requirement was less strict when the aider and abettor received a financial benefit from his participation. ${ }^{28}$

Although secondary liability was not expressly provided for in the original federal securities laws, except for a few limited provisions, secondary liability for aiding and abetting violations of Section 10(b) of the Securities Exchange Act was recognized in all eleven circuits of the Courts of Appeals to have considered the question before $1994 .{ }^{29}$ In 1988, one commentator wrote: "[S]econdary liability ... has become so well established in the securities law that courts rarely question its basis." ${ }^{30}$ In addition to the universal support given by every federal circuit to some form of secondary liability under implied private rights of

proposition that members of a class for whom a statutory duty is created have the right to recover damages from those who disregard the statute)); Cent. Bank of Denver, N.A. v. First Interstate Bank of Denver, N.A., 511 U.S. 164, 192-93 (1994) (Stevens, J., dissenting) ("The early aiding and abetting cases relied upon principles borrowed from tort law; . . . judges closer to the times and climate of the 73d Congress than we concluded that holding aiders and abettors liable was consonant with the Exchange Act's purpose to strengthen the antifraud remedies of the common law.").

24. See generally, Prentice, supra note 6, at 622-30 (describing the common law of fraud as it existed in 1934 when Congress sought to expand investor protection from fraud).

25. See, e.g., Humphreys, supra note 19, at 379-80 (describing the elements required for liability typical in the case law).

26. See, e.g., Woodward v. Metro Bank, 522 F.2d 84, 95 (5th Cir. 1975) (adopting a sliding scale for scienter based on the proximity of the activity).

27. See Kuehnle, supra note 6, at 330 ("Some courts also have adopted an approach of linking the level of knowledge required to the degree of assistance rendered.").

28. See Walck v. Am. Stock Exch., Inc., 687 F.2d 778, 791 n.18 (3d Cir. 1982); Gould v. Am.-Hawaiian S.S. Co., 535 F.2d 761, 780 (3d Cir. 1976) ("The requirement of knowledge may be less strict where the alleged aider and abettor derives benefits from the wrongdoing.").

29. See Cent. Bank of Denver, N.A. v. First Interstate Bank of Denver, N.A., 511 U.S. 164, 192 (1994) (Stevens, J., dissenting) ("All 11 Courts of Appeals to have considered the question have recognized a private cause of action against aiders and abettors under 10(b) and Rule 10b-5.").

30. Kuehnle, supra note 6 , at 315 . 
action in the federal securities laws, both strong policy arguments and the philosophical approach of the U.S. Supreme Court towards securities law suggested that secondary liability was an embedded component of the implied private right of action under Section 10(b). ${ }^{31}$

Secondary liability for commercial fraud was firmly established law prior to passage of the Securities Act and the Securities Exchange Act, in 1933 and 1934, respectively. ${ }^{32}$ Presumably, Congress intended to provide investors with at least as much protection after the Acts as they had before the Acts' enactment, and elimination of secondary liability would be contrary to that presumption. ${ }^{33}$ Furthermore, the Court has recognized the broad remedial intent of Congress under the securities laws and embraced a cumulative approach under which investor protections would cumulate and not be interpreted as exclusive. ${ }^{34}$ Although Supreme Court decisions expressly reserved the question of the existence of aiding and abetting liability for a future case, ${ }^{35}$ lower courts continued to apply the doctrine in all circuits, and the Supreme Court has decided some cases that were close analogies to aiding and abetting securities law violations that arguably supported application of the doctrine. $^{36}$ For example, in Affiliated Ute Citizens $v$. United States, ${ }^{37}$ the Court-without explanation - found a bank secondarily liable for insider trading by its employees. ${ }^{38}$ In a subsequent case not involving securities laws, the Court recognized secondary liability under federal statutory liability holding an employer liable for violations of antitrust law by its employees. $^{39}$ In a decision closer to point, the Court interpreted the

31. Cf. Murdock, supra note 17, at 166-67 (discussing inconsistency between the Central Bank decision and Supreme Court precedent); Marc I. Steinberg, The Ramifications of Recent U.S. Supreme Court Decisions on Federal and State Securities Regulation, 70 Notre Dame L. REV. 489, $489-90$ (1995) ("[T]he [Central Bank] Court misconstrues its own precedent.").

32. See Robert A. Prentice, Scheme Liability: Does It Have a Future after Stoneridge?, 2009 WIS. L. REV. 351, 373-74 (2009) (discussing liability and the many recoveries for participating in fraud under pre-1934 common law).

33. See id. at 358-59 ("Congress believed that it had to enact the Securities Act ... and the Securities Exchange Act . . . because state securities laws and the common law of fraud had been inadequate to the task of protecting investors. . . The purpose of section 10(b) was to expand, not contract, the protections. . ..").

34. Herman \& MacLean v. Huddleston, 459 U.S. 375, 385-87 (1983).

35. See Cent. Bank of Denver, N.A. v. First Interstate Bank of Denver, N.A., 511 U.S. 164, 192 (1994) (Stevens, J., dissenting) ("[W]e have reserved decision on the legitimacy of the theory in two cases that did not present it. . ." (referring to Ernst \& Ernst v. Hochfelder, 425 U.S. 185, 191 n.7 (1976) and Huddleston, 459 U.S. at 379 n.5)).

36. See Kuehnle, supra note 6, at 316-18 (discussing Supreme Court cases in the 1970 's and 1980's that could have supported secondary liability under the federal securities laws).

37. Affiliated Ute Citizens v. United States, 406 U.S. 128 (1972).

38. Id. at 154 .

39. Am. Soc'y of Mech. Eng'rs, Inc. v. Hydrolevel Corp., 456 U.S. 556, 567 (1982). 
Commodity Exchange Act to allow liability under a secondary conspiracy theory, explaining that participants in a conspiracy to manipulate commodity prices are also subject to suit. ${ }^{40}$

Additional cases provide further ammunition for broadly construing investor protections under securities law. For example, in Herman \& MacLean v. Huddleston, ${ }^{41}$ the Court embraced the cumulative remedy approach holding that a plaintiff may maintain an implied cause of action under Section 10(b) for action expressly prohibited under Section 11 of the Securities Exchange Act. ${ }^{42}$ The Court noted the savings clauses included in the ' 33 and ' 34 Acts whereby "Congress rejected the notion that the express remedies of the securities laws would preempt all other rights of action." ${ }^{43}$ The Court also noted the language of the Acts providing that the remedies are "in addition to any and all other rights and remedies that may exist at law or in equity.",44 The Huddleston Court further observed that "[a] cumulative construction of the securities laws also furthers their broad remedial purposes. ${ }^{.45}$

Over time, many commentators have favored the broad remedial construction of the securities laws as an anti-fraud and pro-investor device. ${ }^{46}$ For example, in 1982, Professor Marc Steinberg wrote:

The policy rationale for overlapping remedies is to ensure that the failure of an injured investor to meet the technical requirements for recovering under an express cause of action does not undermine investor protection and the integrity of the marketplace. Proponents of exclusivity, however, assert that the statutory language and legislative history of the express causes of action indicate that to recognize an implied remedy in this context would frustrate the statutory scheme intended by Congress. They conclude that where the plaintiff cannot proceed under an express provision, Congress intended that he not proceed at all. ${ }^{47}$

More recently, in 2008 Professor Robert Prentice observed:

When Congress legislated in 1934, the common law of fraud and virtually every existing body of fraud jurisprudence imposed liability

40. See Merrill Lynch, Pierce, Fenner \& Smith, Inc. v. Curran, 456 U.S. 353, 394 (1982).

41. Herman \& MacLean v. Huddleston, 459 U.S. 375 (1983).

42. Id. at 386-87.

43. Id. at 383 .

44. Id.

45. Id. at 386 .

46. See, e.g., Alan R. Bromberg \& Lewis D. Lowenfels, Securities Fraud \& COMMODITIES FRAUD $\S 2: 69$ (2010) (describing authority for broad cumulative interpretation of $\S 10(\mathrm{~b}))$.

47. Marc I. Steinberg, The Propriety and Scope of Cumulative Remedies Under the Federal Securities Laws, 67 CORNELL L. REV. 557, 559 (1982) (footnotes omitted). 
upon those who knowingly participated in a fraud. It is nearly inconceivable that a Congress legislating in 1934 (or an SEC making rules in 1942) would have intended anything else for the broadly drawn Section 10(b)/Rule 10b-5... [I]t would have been superfluous to have included an express provision imposing a form of aiding and abetting secondary liability when, given the existing state of the law, Congress would necessarily have envisioned that knowing participation in securities fraud would result in joint and several liability. ${ }^{48}$

In between these commentators the SEC argued in a brief that there are two important reasons for maintaining expansive liability in private litigation: to deter fraud and to make investors whole. ${ }^{49}$ This overall philosophy favors a private right of action for aiding and abetting violations of securities laws.

Although the Court expressly reserved a decision about the viability of secondary liability under the securities laws in decisions made in the 1970's and 1980's, it came tantalizingly close to giving approval in dicta. $^{50}$ In Herman \& MacLean v. Huddleston, the Court wrote in a footnote:

The trial court also found that Herman \& MacLean had aided and abetted violations of $\S 10(\mathrm{~b})$. While several Courts of Appeals have permitted aider-and-abettor liability, see IIT, An International Investment Trust v. Cornfeld, 619 F.2d 909, 922 (CA2 1980) (collecting cases), we specifically reserved this issue in Ernst \& Ernst v. Hochfelder, [425 U.S. 185,] 191-192, n. 7 [(1976)]. Cf. Merrill Lynch, Pierce, Fenner \& Smith, Inc. v. Curran, 456 U.S. 353, 394 (1982) (discussing liability for participants in a conspiracy under analogous Commodity Exchange Act provision). ${ }^{51}$

The passage cited by the Court in this $c f$. cite reads, "[I]t necessarily follows that those persons who are participants in a conspiracy to manipulate the market in violation of those rules are also subject to suit by futures traders who can prove injury from these violations." 52 Given the similarity in the language and intent of the Commodity Exchange Act

48. Prentice, supra note 6, at 622-23 (footnotes omitted) (emphasis in original).

49. Brief for the SEC in Support of Respondents, Cent. Bank of Denver, N.A. v. First Interstate Bank of Denver, N.A., 511 U.S. 164 (1994) (No. 92-854), 1993 U.S. S. Ct. Briefs LEXIS 444 at $* 32$ (arguing that private actions against culpable parties assist the SEC in deterring fraud and serves as the primary method of compensating victims).

50. See Humphreys, supra note 19, at 378 ("If this [Hochfelder] cite [to Huddleston] was intended to forecast a future ruling on the existence of the cause of action, aiding and abetting liability will likely be recognized.").

51. Herman \& MacLean v. Huddleston, 459 U.S. 375, 379 n.5 (1983).

52. Merrill Lynch, Pierce, Fenner \& Smith, Inc. v. Curran, 456 U.S. 353, 394 (1982) 
compared with the Securities Exchange Act, it would be reasonable to conclude that liability would also accrue to participants for a violation of the Securities Exchange Act rules given the language used and cited by the Court. ${ }^{53}$

Accordingly, it was not unreasonable for a leading securities law casebook in 1986 to state, "Virtually every lower court decision that has addressed the issue, however, has recognized the propriety of imposing such liability in appropriate circumstances." 54 Furthermore, this scholar argued:

When Congress substantially revised the securities laws in 1975, a plethora of lower courts (including every appellate court that considered the question) had recognized the propriety of aider and abettor liability. Accordingly, relying upon the thrust of Curran and Huddleston, "[i]n light of this well-established judicial interpretation, Congress' decision to leave [aider and abettor liability] intact suggests that Congress ratified the [propriety of this type of liability]., 55

\section{B. Policy Arguments for Aiding and Abetting Liability}

Of course policy arguments also strongly favor liability for aiding and abetting. ${ }^{56}$ There were, and still are, strong policy arguments supporting the doctrine of private action liability for aiding and abetting violations of securities laws. ${ }^{57}$ Aside from the obvious benefit of providing redress for defrauded investors against culpable parties, the doctrine fosters a culture of ethical behavior in the financial marketssomething that is sorely needed today. ${ }^{58}$ If accountants, auditors, and bankers know that assisting in a fraud can subject them to private

53. See Kuehnle, supra note 6, at 317 ("Thus, it appears [based on Curran] that the Court is not adverse to the use of secondary liability in federal law in general or in the securities laws in particular.").

54. Marc I. STeinberg, Securities Regulation 515 (1986).

55. Id. at 516 (citing Curran, 456 U.S. at 387; Huddleston, 459 U.S. at 385-86) (alterations in original)

56. See Brief for the SEC in Support of Respondents, Cent. Bank of Denver, N.A. v. First Interstate Bank of Denver, N.A., 511 U.S. 164 (1994) (No. 92-854), 1993 U.S. S. Ct. Briefs LEXIS 444 at *32 (arguing that private actions against culpable parties assist the SEC in deterring fraud and serves as the primary method of compensating victims).

57. See id.

58. As the author has previously explained:

$[P] r e c i s e$ rules can have the effect of encouraging everyone to operate in the ethical gray zone. The expressed minimum standard of conduct becomes acceptable. What is not expressly prohibited becomes ethical. Conversely, a rule imposing liability for less than full and fair disclosure should lead to disclosure in questionable matters.

Klock, supra note 10, at 106. 
litigation and liability they will have powerful incentives not to provide such assistance and will be less likely to do so. ${ }^{59}$ On the other hand, if accountants, auditors, and bankers know that they can provide assistance in a fraud as long as they stay in the safe harbor of avoiding direct transactions and communications with investors, then they clearly have no economic incentive operating as a deterrent. ${ }^{60}$ There are virtually zero meritorious policy arguments against liability for aiding and abetting fraud. ${ }^{61}$ The only argument that can be made against this liability is quite simply the narrow legal argument that since Congress did not expressly write it into the law, Congress did not intend it. ${ }^{62}$

When the Supreme Court ultimately addressed the question of secondary liability under the securities laws, this was their only argument against secondary liability-that the original laws were largely silent as to the availability of redress against secondary actors and, therefore, where Congress did not expressly provide for it, it should not be available. $^{63}$ However, that argument can easily be turned around to suggest that where Congress did not expressly exclude redress, it should be available. ${ }^{64}$ Even more persuasive, however, is the context of the law as it existed in 1934. Professor Prentice conducts a careful and

59. See, e.g., Klock, supra note 4, at 835 ("Only with the threat of private enforcement actions will the players in the markets have sufficiently strong incentives to play honestly and conduct their business with integrity.").

60. One practicing securities lawyer recently commented on the current state of the law:

[A] professional can rest easy so long as the attorney, CPA, and investment banker make no statements to the public. It appears no matter their culpability, they will escape private civil liability under $\S 10(\mathrm{~b})$ and the Rule. The lawyer that works, plans and schemes with his client to deceive and defraud the investing public, but who is careful to make no public statements, is free of civil liability....

Stuart Sinai, Stoneridge-Escape from Securities Liability Notwithstanding Active, Intentional, Deceptive Conduct, 8 J. BUS. \& SEC. L. 170, 187 (2008).

61. In theory, one could make a policy argument that litigation is costly, therefore we should proscribe large categories of potential litigation against culpable wrongdoers, but this argument is so specious I will not give it attention beyond this note.

62. Indeed, this is the only argument regarding aiding and abetting given by the majority in the Stoneridge decision. See Stoneridge Inv. Partners, LLC v. ScientificAtlanta, Inc., 552 U.S. 148, 162 (2008) ("Congress amended the securities laws to provide for limited coverage of aiders and abettors. Aiding and abetting liability is authorized in actions brought by the SEC but not by private parties.").

63. See Cent. Bank of Denver, N.A. v. First Interstate Bank of Denver, N.A., 511 U.S. 164, 177 (1994) ("[T] the text of the 1934 Act does not itself reach those who aid and abet a $10(\mathrm{~b})$ violation. ... [T] [That conclusion resolves the case.").

64. See Kuehnle, supra note 6, at 316 (asserting that Congress recognized that secondary liability for fraud was part of the common law and that logic dictates that Congress did not intend to contract liability, and further suggesting that Congress' failure to expressly exclude this liability favors its application). 
comprehensive historical analysis of the law as it existed in 1934 and writes:

In 1934, aiding or aiding and abetting were not viewed as separate, lesser wrongs that might not justify imposition of liability, and Congress simply would not have considered them as such.... Participation in a tort made a defendant a joint tortfeasor, and joint tortfeasors were equally liable in the eyes of the law....

It is undeniable that, given the state of the law in 1934, a Congress contemplating a private right of action absolutely must have expected liability to be visited upon defendants [assisting in securities fraud]. ${ }^{65}$

Professor Prentice concludes that the Court made an error in Central Bank, which it compounded further in Stoneridge by defining primary liability narrowly. ${ }^{66}$

Other securities scholars have also suggested that the subsequent overhaul of the securities laws by Congress that did not expressly exclude aiding and abetting liability when Congress knew well that courts were applying it constituted Congressional affirmation of the doctrine. ${ }^{67}$ Yet another early commentator persuasively advocated for aiding and abetting liability:

A barring of secondary liability would be a rejection of longrecognized principles and would produce, contrary to the purpose of the federal securities laws, investor protections that in many cases would be less than existed at common law. The statutory controlling person provisions were not intended to preclude other forms of secondary liability, but were intended to provide an additional basis of liability to control misconduct that otherwise might not be covered. $^{68}$

Thus, policy arguments twenty years ago favored the imposition of liability for participating in fraud, and the law of the land actually was that aiding and abetting violations of securities laws would subject one to civil liability in private actions. ${ }^{69}$ The Circuits were split as to the extent

65. Prentice, supra note 6 , at 629 .

66. Id. at 682-83.

67. See, e.g., STEINBERG, supra note 54, at 516 (suggesting that Congressional silence on aiding and abetting when it overhauled securities laws knowing that courts were applying it constituted ratification). See also Cent. Bank, 511 U.S. at 197 (Stevens, J., dissenting) ("[T]he available evidence suggests congressional approval of aider and abettor liability in private $\S 10(\mathrm{~b})$ actions. In its comprehensive revision of the Exchange Act in 1975, Congress left untouched the sizable body of case law approving aiding and abetting liability in private actions....").

68. Kuehnle, supra note 6, at 376.

69. See, e.g., Nathan F. Coco, Comment, Has Legislative History Become History?: A Critical Examination of Central Bank of Denver, N.A. v. First Interstate Bank of 
and scope of aiding and abetting securities fraud liability, but there was no split as to its existence. ${ }^{70}$ The landscape changed completely in 1994 with the still shocking decision in Central Bank. ${ }^{71}$

\section{The Demise of Aiding and Abetting Liability}

Central Bank involved the following fact pattern. A public authority issued bonds in the public market to finance building improvements. ${ }^{72}$ Central Bank of Denver served as the indenture trustee for the bonds. ${ }^{73}$ The bonds were backed by collateral in the form of real property, and the bond indenture required that the value of the property be worth at least $160 \%$ of the bonds' outstanding principal and interest. ${ }^{74}$ The bond covenants required the developer to give Central Bank an annual report with evidence that the $160 \%$ test was satisfied. ${ }^{75}$ In January of 1988 , the developer provided Central Bank with an updated land appraisal of the collateral securing the bonds issued in 1986 and proposed to secure new bonds for 1988 issuance. $^{76}$ Central Bank realized that the 1988 appraisal showed the land values had not changed much since 1986 but knew that property values in the area had been falling. ${ }^{77}$

Knowing that the appraisal was stale and optimistic, Central Bank decided that a new appraisal should be conducted, but subsequently decided to delay the appraisal until the end of the year, six months after

Denver, N.A., 20 IOWA J. CORP. L. 555, 561 (1995) ("It is remarkable that the majority was willing, if not eager, to unabashedly cast aside the principle of stare decisis to vacate an aiding and abetting doctrine that had been upheld in every circuit for several decades.").

70. Id.

71. See Cent. Bank, 511 U.S. at 196-98 (Stevens, J., dissenting) (criticizing the Court for changing a firmly established legal construction of $\S 10(\mathrm{~b})$ ). See also Douglas M. Branson, Running the Gauntlet: A Description of the Arduous, and Now Often Fatal, Journey for Plaintiffs in Federal Securities Law Actions, 65 U. CIN. L. REV. 3, 11 (1996) ("[In Central Bank] [t] he Supreme Court reversed twenty-five years of reliance on the common-law construct of aiding and abetting by lower federal courts to hold collateral participants to securities transactions secondarily liable."); James D. Cox, Just Deserts for Accountants and Attorneys After Bank of Denver, 38 ARIZ. L. REV. 519, 545 (1996) ("The Supreme Court discarded a doctrine that had not only been accepted by all the circuits but had matured and become predictable, and there was no evidence the doctrine had created mischief in its wake."); Steinberg, supra note 31, at 489-90 ("The Court's decision swept away decades of lower court precedent that nearly universally recognized the propriety of such secondary liability under the statue and rule.").

72. Cent. Bank, 511 U.S. at 167.

73. Id.

74. Id.

75. Id.

76. Id.

77. Id. 
the June closing on the 1988 bonds. $^{78}$ After the 1988 bonds were issued and before a new appraisal was completed, the borrower defaulted on the 1988 bonds. $^{79}$ Plaintiffs sought to hold Central Bank liable for aiding and abetting the borrower's fraud by delaying its independent evaluation of the value of the collateral until after the new bonds were issued. ${ }^{80}$ The trial court granted summary judgment for Central Bank, but the Court of Appeals for the Tenth Circuit reversed. ${ }^{81}$

In a decision that literally shocked the securities bar, ${ }^{82}$ the Supreme Court reversed and held that there is no liability for aiding and abetting securities laws. ${ }^{83}$ The decision ignored decades of precedent in all federal circuits and discarded a well-established doctrine without any evidence that the doctrine was causing mischief. ${ }^{84}$ Indeed, subsequent financial scandals of enormous magnitude suggest that the doctrine was working to promote integrity and ethical behavior in the public markets. ${ }^{85}$ The Court reasoned that because Congress did not expressly provide for aiding and abetting liability in the express causes of action given in the securities laws, there was no aiding and abetting liability for either express or implied causes of action. ${ }^{86}$ The Court further reasoned that there was no applicable body of federal common law and that "Congress has not enacted a general civil aiding and abetting statute. . ..,87

The decision stunned the securities bar because it was so overreaching it addressed questions that the petitioner did not even put before the Court. ${ }^{88}$ Even the petitioner assumed that a private cause of

78. Id. at 168 .

79. Id.

80. Id.

81. Id.

82. See, e.g., Steinberg, supra note 31, at 489 ("In a decision that delighted 'deep pockets,' shocked the plaintiffs' bar, and befuddled neutral observers, the Supreme Court . . . held that aiding and abetting liability in private actions may not be imposed under section 10(b) of the Securities Exchange Act of 1934 ("Exchange Act") or under rule 10b-5.") (internal citations omitted).

83. Cent. Bank, 511 U.S. at 191.

84. See id. at 199-201 (Stevens, J., dissenting) (noting that the Court is lopping off rights that have been recognized for decades without suggesting that the doctrine caused any deleterious effects).

85. See Coffee, supra note 9, at 288-90 (arguing that Central Bank contributed to an increase in auditor acquiescence of financial fraud); Murdock, supra note 17, at 167 ("[T]he elimination of the accountability imposed by aiding and abetting liability, arguably [contributed] to the dereliction of responsibility by accountants and lawyers later in the decade. ... Arthur Andersen went from a paragon of virtue at the start of the 1990 s to an indicted felon at the start of the 2000s.").

86. Cent. Bank, 511 U.S. at 177.

87. Id. at 182 .

88. Id. at $194-95$ (Stevens, J., dissenting). 
action for aiding and abetting securities fraud existed. ${ }^{89}$ The petitioner merely challenged whether the action could be applied in a case of recklessness or negligence without actual intent. ${ }^{90}$ A large volume of commentary criticized the decision, and even symposia were held on the case. $^{91}$ The criticism of the decision was largely a reiteration of what was stated in the dissent by four justices and authored by Justice Stevens:

In hundreds of judicial and administrative proceedings in every Circuit in the federal system, the courts and the SEC have concluded that aiders and abettors are subject to liability under $\S 10(\mathrm{~b})$ and Rule $10 \mathrm{~b}-5 . .$. While we have reserved decision on the legitimacy of the theory in two cases that did not present it, all 11 Courts of Appeals to have considered the question have recognized a private cause of action against aiders and abettors under $\S 10(\mathrm{~b})$ and Rule $10 \mathrm{~b}-5^{92}$

The dissent continues with the argument that the reasons given by the majority against construing a private cause of action are not sufficient to take away a long held and firmly established right that fits comfortably within the statutory scheme. ${ }^{93}$ Justice Stevens suggests that judicial restraint would favor not acting to take away rights under established law, and that it should be up to Congressional action to legislate changes in established law. ${ }^{94}$ Finally, as a matter of policy, the dissent also notes that the SEC had used aiding and abetting liability as an important tool in its enforcement arsenal for deterring fraud, and the majority unambiguously removed that tool from the SEC. ${ }^{95}$

This far overreaching majority decision in Central Bank-that aiding and abetting securities fraud is not illegal-was so offensive that in a rare move Congress legislatively changed the law. ${ }^{96}$ In passing the

89. Id. at 194 .

90. Id.

91. See, e.g., Therese H. Maynard, Central Bank: The Methodology, The Message, and The Future, 29 LOY. L.A. L. REV. 1 (1995) ("In the spring of 1994, the Supreme Court handed down a bombshell of an opinion in Central Bank v. First Interstate Bank. ... The Supreme Court's Central Bank opinion sparked an intense response from all quarters that even addressed issues beyond the Supreme Court's narrow holding."). Even after fifteen years, commentators continue to analyze and criticize the decision. Murdock, supra note 17, at 163-67. In particular, note the harsh comment, "The reasoning is actually embarrassing." $I d$. at 164 .

92. Cent. Bank, 511 U.S. at 192 (Stevens, J., dissenting).

93. Id. at 196-97.

94. Id. at 198 .

95. Id. at 200.

96. See Stoneridge Inv. Partners, LLC v. Scientific-Atlanta, Inc., 552 U.S. 148, 158 (2008) ("The decision in Central Bank led to calls for Congress to create an express cause of action for the SEC to bring enforcement actions for aiding and abetting within the Securities Exchange Act. . . . Congress . . . directed prosecution of aiders and abettors by the SEC."'). 
1995 Private Securities Litigation Reform Act (the "PSLRA"), Congress expressly provided that aiding and abetting violations of the securities law is illegal and enforceable by the SEC. ${ }^{97}$ The exact words of the Congressional Act include,

[A]ny person that knowingly or recklessly provides substantial assistance to another person in violation of a provision of this title [15 U.S.C. $\S \S 78 \mathrm{a}$ et seq.], or of any rule or regulation issued under this title [15 U.S.C. $\$ \S 78 \mathrm{a}$ et seq.], shall be deemed to be in violation of such provision to the same extent as the person to whom such assistance is provided. ${ }^{98}$

Unfortunately for defrauded investors, the PSLRA only clearly imposed liability in actions brought by the SEC. ${ }^{99}$ Whether the reform reestablished the availability of aiding and abetting claims for private party litigation remained a matter of some debate. ${ }^{100}$

On the one hand, the fact that Congress expressly made aiding and abetting violations of the securities laws illegal and punishable by the SEC could be interpreted as an argument that Congress did not intend to give the right to private individuals to recover. ${ }^{101}$ However, this could be giving too much weight to inaction by Congress. ${ }^{102}$ By the time the PSLRA was passed, lower courts had begun interpreting primary liability broadly and imposing liability on collateral agents who substantially participated in a scheme to defraud. ${ }^{103}$ Thus, Congress did not need to expressly create a remedy for private investors. ${ }^{104}$ However, the Supreme Court's holding in Central Bank had brought into question whether the SEC was also prohibited from pursuing individuals that aided and abetted securities fraud. ${ }^{105}$ Congress needed to act to clarify this problem. ${ }^{106}$ Arguably, by expressly making aiding and abetting

97. Private Securities Litigation Reform Act of $1995 \S 104,109$ Stat. 737, 757 (codified as amended at 15 U.S.C. § 78t(e) (2006)).

98. Id.

99. See Stoneridge, 552 U.S. at 163 ("[W]e give weight to Congress' amendment to the Act restoring aiding and abetting liability in certain cases but not others.").

100. See Klock, supra note 14, at 322 (discussing arguments for and against inferring the availability of private enforcement against expressly illegal conduct).

101. Stoneridge, 552 U.S. at 158.

102. See Prentice, supra note 6, at 648-51 (discussing reasons that legislative silence on private remedies should not be interpreted as an intent to limit private remedies).

103. Id. at 648-49.

104. Id. at 649.

105. See SteInBerg, supra note 11, at 762 ("After Central Bank of Denver, many observers believed that the decision's rationale extended to SEC enforcement actions.").

106. See Cox, supra note 71, at 537 ("The Reform Act confirms the SEC's authority to judicially prosecute knowing aiders and abettors. ... Not to have so acted would have seriously undercut the regulatory balance Congress had recently created within the SEC enforcement arsenal...."). 
securities fraud illegal in enforcement actions by the SEC and remaining silent on the question of private actions, Congress could have meant to provide private plaintiffs the ability to recover from aiders and abettors, or those who substantially participated in a scheme. ${ }^{107}$ However, the Court resolved the question in 2008 in yet another far overreaching decision that effectively immunized a broad class of undefined individuals from private liability in securities fraud. ${ }^{108}$

\section{Stoneridge-Further Squashing Private Actions}

Stoneridge was widely proclaimed to be the Roe $v$. Wade of securities law. ${ }^{109}$ The facts of the case are complicated, but easy to summarize. Charter Communications was the fourth largest cable company in the U.S. and an S\&P 500 firm trading on the NYSE with a large equity capitalization of several billion dollars. ${ }^{110}$ Analysts had projected Charter's annual earnings to be in the neighborhood of twenty million dollars higher than what Charter's officers thought they would make. ${ }^{111}$ When the officers of Charter realized that their earnings would fall significantly short of analyst estimates, they devised a plan to inflate reported earnings and fool their auditors. ${ }^{112}$

Charter had been purchasing set-top cable boxes from vendors such as Scientific-Atlanta and Motorola. ${ }^{113}$ Charter proposed that they would overpay $\$ 20$ for each of the boxes bought for the remainder of the year, but in exchange the companies would return this overpayment to Charter in the form of "purchasing" advertising from Charter. ${ }^{114}$ This would increase Charter's revenue enough to meet the earnings expectations. ${ }^{115}$ There would not be an offsetting expense in Charter's financial statements because at the new higher cost, Charter would treat the

107. See Prentice, supra note 6, at 649-51 (arguing that Congress sought to expand investor protection in 1995 and recognized private rights of action as an essential component of investor confidence and market integrity).

108. See Stoneridge Inv. Partners, LLC v. Scientific-Atlanta, Inc., 552 U.S. 148, 158 (2008) (holding that there is no implied private right of action against mere aiders and abettors notwithstanding the PSLRA).

109. Nicholas Rummell, Supremes to Weigh in on Vendor Liability for Fraud, FIN. WK., Oct. 8, 2007, at 1.

110. Charter Communications, Inc., Annual Report (Form 10-K) (Feb. 26, 2010), available at http://phx.corporate-ir.net/External.File?item=UGFyZW50SUQ9NjcyOTF 8Q2hpbGRJRD0tMXXUeXBIPTM=\&t=1 (last visited Oct. 17, 2011).

111. Stoneridge, 552 U.S. at 153.

112. Franklin A. Gevurtz, Law Upside Down: A Critical Essay on Stoneridge Investment Partners, LLC v. Scientific-Atlanta, Inc., 103 NW. U. L. REV. COLLOQUY 448, 449 (2009).

113. Stoneridge, 552 U.S. at 154.

114. Id.

115. $I d$. 
purchases as capital expenditures rather than expense items and would accordingly depreciate the cost charges over time. ${ }^{116}$ Although these transactions were a wash and should have been treated as such, Charter's officers and the officers of their vendor corporations drafted separate documents relating to the price change and the advertising revenue and backdated some of these so as to create the appearance of independence in the transactions and fool the auditors of Charter. ${ }^{117}$ When the subsequent financial fraud was discovered, investors that lost money brought suit and included Scientific-Atlanta and Motorola as defendants in the action. ${ }^{118}$

The district court dismissed the claim against Charter's vendors in a motion for summary judgment, and the Court of Appeals for the Eighth Circuit affirmed. ${ }^{119}$ The Supreme Court granted a writ of certiorari to consider the case and also affirmed in a five to three decision. ${ }^{120}$ The three dissenting justices would have reversed on the theory that the knowingly fraudulent conduct by the respondents was a but for cause of the financial fraud and made them primarily liable jointly with Charter for using a "deceptive device" prohibited by $\S 10 \mathrm{~b}$ of the Securities Exchange Act. ${ }^{121}$ However, the majority concluded that the respondents were at most aiders and abettors ${ }^{122}$ and, therefore, not liable because there is no private right of action against aiders and abettors. ${ }^{123}$

Critical commentary sided with the dissent and accused the majority of overreaching to find no primary liability solely to stomp out any remaining life in aiding and abetting liability. ${ }^{124}$ The majority's rationale for finding no primary liability was that the vendors made no fraudulent representations to the shareholders of Charter. ${ }^{125}$ This is true, but as the

\footnotetext{
116. Id.

117. Id. at $154-55$.

118. Id. at 155 .

119. Id.

120. Id. at 151 .

121. Id. at 167 (Stevens, J., dissenting).

122. Id. at 166-67.

123. Id. at 158.

124. See, e.g., Prentice, supra note 6, at 683 ("The Central Bank/Stoneridge holding that collateral parties who knowingly participate in fraudulent schemes are merely 'secondary' parties who cannot be held liable is utterly inconsistent with every relevant body of fraud law in existence in 1934."); Sinai, supra note 60, at 173 ("The dissent in Stoneridge made clear that the majority had based its views on 'faulty premises."'); Klock, supra note 14, at 327 ("The Stoneridge majority has created a contrived distinction for the purpose of eliminating liability by the perpetrator of a but-for cause of the securities fraud. The distinction between preparing the financial statements and providing the sham transactions upon which the financial statements were based is arbitrary and whimsical.") (footnote omitted); Murdock, supra note 17, at 207 ("In his dissent, Justice Stevens took the majority to task.").
}

125. Stoneridge, 552 U.S. at 166-67. 
dissenters point out, the decision creates a new super-causation requirement under $\S 10 \mathrm{~b} .{ }^{126}$ According to the majority, investors have no claim against Scientific-Atlanta and Motorola because their fraudulent communications went to Charter's auditors and not to Charter's shareholders. ${ }^{127}$ This is a ridiculous distinction since the fraudulent financial statements would not have entered the marketplace if not for the fraudulent documentation by the respondents. ${ }^{128}$ The majority's reasoning and finding are contrary to Congressional intent to provide broad remedial legislation designed to deter fraud, assist victimized investors, and install confidence in the integrity of the marketplace. ${ }^{129}$

Having decided that the respondents were not primarily liable under $\S 10$ (b) because the fraudulent activity took place in the market for goods and services rather than the market for securities, the majority then had a platform to rule that aiding and abetting violations of the federal securities laws does not create liability to private plaintiffs. ${ }^{130}$ The Court first cited its holding in Central Bank that $\S 10(\mathrm{~b})$ does not extend liability to aiders and abettors. ${ }^{131}$ The Court next observed that Congress reacted to Central Bank by expressly making aiding and abetting a violation of the federal securities laws actionable in proceedings brought by the SEC. ${ }^{132}$ The Court interpreted this as an intention not to provide a private right of action against aiding and abetting a violation of the federal securities laws. ${ }^{133}$ As a result, investors will have no remedy against this type of misconduct unless they can persuade the SEC to use

126. Id. at 168 (Stevens, J., dissenting).

127. See id. at 160 (stating that acts designed to assist fooling auditors about the revenue that becomes disclosed in public filings are too remote to support investor reliance on the deceptive acts).

128. See Klock, supra note 14, at 326-27 (discussing the connection between product market transactions and financial market prices); Murdock, supra note 17, at 206 ("Financial statements are not some abstraction, of value in and of themselves. Financial statements only have value to the extent they accurately reflect the underlying transactions.").

129. See Stoneridge, 552 U.S. at 179 (Stevens, J., dissenting) ("In light of the history of court-created remedies and specifically the history of implied causes of action under $\S 10(b)$, the Court is simply wrong when it states that Congress did not impliedly authorize this private cause of action "when it first enacted the statute."').

130. See Prentice, supra note 6, at 651 (explaining that because the Stoneridge defendants were involved in such blatant fraud, the majority could not merely label them aiders and abettors without first ruling erroneously that the investors did not rely on the defendants' acts); Klock, supra note 14, at 333 ("In order to have the opportunity to limit the language [of the PSLRA] providing for secondary liability, it was necessary for the Court to reach the conclusion that there was insufficient causal connection between the conduct and the fraud in the financial market.").

131. Stoneridge, 552 U.S. at 157.

132. See id. at 158.

133. Id. 
its limited enforcement resources to pursue aiding and abetting violations. $^{134}$

The SEC's ability to pursue aiders and abettors of securities fraud was no consolation to the investors of Charter. Not only did the SEC not prosecute Motorola and Scientific-Atlanta for aiding and abetting fraud, even though the defendants were obviously culpable, but the United States actually filed an amicus brief on behalf of the less than ethical defendants arguing against private action civil liability. ${ }^{135}$ So much for the notion that one role of government is to protect its citizens. It is also worth noting that the SEC's limited resources were not sufficient to detect the sixty billion dollar Madoff fraud conducted over two decades even when the evidence was gift wrapped and delivered to them. ${ }^{136}$ This will be discussed further in Part V. Clearly, without a private right of action there is no incentive for corporations to avoid the type of unethical behavior engaged in by Motorola and Scientific-Atlanta. ${ }^{137}$

After the decision in Stoneridge, Senator Carl Levin criticized the Court's policy and called on Congress to change the law. ${ }^{138}$ Senator Levin stated:

In Stoneridge, the Supreme Court determined that shareholders are barred by federal law from suing third parties that help public companies commit fraud, and must instead rely on federal regulators to punish wrongdoing and recover funds. Given limited federal resources, however, that ruling means, in too many cases, banks, accounting firms, lawyers and others will be able to aid and abet corporate fraud, and shareholders will have no legal recourse. That isn't fair, and it undermines investor confidence in U.S. markets. ${ }^{139}$

134. Id

135. Brief for the United States as Amicus Curiae Supporting Affirmance, Stoneridge Inv. Partners, LLC v. Scientific-Atlanta, Inc., 522 U.S. 148 (2008) (No. 06-43), 2007 WL 2329639.

136. See generally Rhee, supra note 4, at 363-84 and Klock, supra note 4, at 784-819 (describing and analyzing the failure of the SEC to uncover Madoff's fraud).

137. See, e.g., Murdock, supra note 17, at 134-35. Professor Murdock asserts:

[C]ourts and legislatures . . . are biased in favor of management; moreover that their failure to hold management to account has emboldened management to engage in illicit behavior and has led to supineness, or worse, by gatekeepers, such as accountants and boards of directors. The willingness of federal courts to disregard blatant corruption and give crooks a free pass by engaging in outcome determinative decision making and strained interpretations of the Id. law....

138. Where Were Watchdogs? Financial Crises and Breakdown of Financial Governance: Hearing Before the S. Comm. on Homeland Sec. \& Gov. Affairs, $111^{\text {th }}$ Cong. 354-355 (Jan. 21, 2009) (statement of Sen. Carl Levin, Chairman, Perm. Subcomm. on Investigations).

139. Id. at 354 . 
Unfortunately, Senator Levin's proposal has not been acted on.

\section{The AfTERMATH OF CENTRAL BANK-AN EPIDEMIC OF FINANCIAL SCANDALS}

\section{A. Review of the Enron Fraud}

The beginning of the new millennium was accompanied by an epidemic of financial scandals that received high visibility and generated many calls for reform and historical analysis. ${ }^{140}$ AOL, Halliburton, WorldCom, Qwest, Tyco, AIG, Parmalat, and many other well-known large corporations were caught in accounting scandals misstating costs, revenues and earnings. ${ }^{141}$ The largest among all of these was Enron. ${ }^{142}$

Enron was a large energy company that began developing new products and experienced rapid growth. ${ }^{143}$ As the stock market came to capitalize Enron's growth into the price of the shares, pressure to maintain the growth increased. ${ }^{144}$ This led to aggressive and risky investments, some of which did not go well. ${ }^{145}$ Enron set up derivatives positions with phony companies in order to hide their losses. ${ }^{146}$ Meanwhile, their losses grew and became more difficult to hide. ${ }^{147}$ Eventually, the dam broke and company officials and consultants and

140. See Coffee, supra note 9, at 269-71 (observing the explosion of scandals occurring around 2001-2002 and noting that scandals tend to create legislation).

141. See, e.g., Faith Stevelman, Corporate Governance Five Years After SarbanesOxley: Is there Real Change?: Foreword, 52 N.Y.L. SCH. L. REv. 475, 481 n.29 (2005).

142. Klock, supra note 10 , at 69 n. 1 .

143. Newby v. Enron Corp., 394 F.3d 296, 299 (5th Cir. 2004).

144. See Marianne M. Jennings, A Primer on Enron: Lessons From a Perfect Storm of Financial Reporting, Corporate Governance and Ethical Culture Failures, 39 CAL. W. L. REV. 163, 172-73 (2003) (describing the pressure on Enron resulting in creative accounting).

145. See Richard D. Cudahy \& William D. Henderson, From Insull to Enron: Corporate (Re)Regulation after the Rise and Fall of Two Energy Icons, 26 ENERGY L.J. 35, 91 (2005) (describing Enron's aggressive business practices and collapse).

146. See Lawrence A. Cunningham, The Sarbanes-Oxley Yawn: Heavy Rhetoric, Light Reform (And It Just Might Work), 35 CoNN. L. Rev. 915, 928-29 (2003).

147. Two reporters described Enron's troubles:

[A]s Enron's trading expanded, its other businesses underperformed. Its debt and cash needs kept growing, so the company needed to make more and bigger "structured transactions" to keep the game going-pledging increasing amounts of stock. Enron's strategy began to resemble what members of Congress would later call a high-tech Ponzi scheme.

April Witt \& Peter Behr, Visionary's Dream Led to Risky Business: Opaque Deals, Accounting Sleight of Hand Built an Energy Giant and Ensured Its Demise, WASH. Post, July 28,2002 , at A01. 
auditors for Arthur Anderson were caught shredding documents in a last minute effort to destroy evidence of blatant criminal fraud. ${ }^{148}$

Investors lost billions of dollars. ${ }^{149}$ Many lawsuits were filed. ${ }^{150}$ As Enron and Arthur Anderson went into bankruptcy, plaintiffs naturally looked to other culpable deep pockets for recovery. One extremely visible case provided an illustrative example of one of Enron's egregious frauds. The University of California's Board of Regents had invested heavily in Enron and was the lead plaintiff in a class-action against defendants including Merrill Lynch. ${ }^{151}$ In a transaction now known as the Nigerian Barges Transaction, Enron hid significant bad assets on its books and obtained a large amount of cash in an unprofitable deal that dressed up the corporate financial statements. ${ }^{152}$ The company "sold" Nigerian registered barges to Merrill Lynch with a promise to buy them back in six months at a profit to Merrill Lynch. ${ }^{153}$ The economic substance of such a transaction is a loan of cash by Merrill Lynch to Enron secured by the barges as collateral, with a profitable interest rate on the loan for Merrill. ${ }^{154}$ However, rather than book the transaction as a loan, it was recorded as a sale of assets; this procedure removed bad assets and increased cash which effectively made Enron appear to have more liquidity and less debt than was actually the case. ${ }^{155}$

Knowing that aiding and abetting securities fraud did not provide a strong legal theory for recovery, the plaintiffs' lawyers sought to recover under a theory of scheme liability. ${ }^{156}$ This theory proposed that Merrill Lynch played such an important role in the scheme to defraud Enron investors that Merrill should also be held liable as a primary violator. ${ }^{157}$ The Court of Appeals for the Fifth Circuit held otherwise. ${ }^{158}$ In

148. See April Witt \& Peter Behr, Losses, Conflicts Threaten Survival: CFO Fastow Ousted In Probe of Profits, WASH. POST, July 31, 2002, at A01 (describing the document shredding).

149. See David A. Westbrook, Corporation Law After Enron: The Possibility of a Capitalist Reimagination, 92 GEO. L.J. 61, 64 (2003) (describing the magnitude of losses and stock price movements).

150. See, e.g., Newby v. Enron Corp., 302 F.3d 295, 298 (5th Cir. 2002) (noting one law firm's consolidation of numerous private plaintiff securities law civil actions into several certified class actions).

151. Regents of the Univ. of Cal. v. Credit Suisse First Bos., Inc., 482 F.3d 372 (5th Cir., 2007), cert. denied, 552 U.S. 1170 (2008).

152. Id. at 377 .

153. Id.

154. Id.

155. Id

156. See id at 378 (describing district court's finding in support of plaintiff's legal theory).

157. See id. at 377 ("Plaintiffs allege that the banks knew exactly why Enron was engaging in seemingly irrational transactions. . ..").

158. Id at 394 
reasoning that might well have been borrowed by the five Supreme Court Justices in their subsequent Stoneridge opinion, the Fifth Circuit held that Merrill Lynch's conduct was not covered under the securities laws because their actions were not something that investors in an efficient market could be presumed to have relied on. ${ }^{159}$

\section{B. Market Efficiency and Fraud-on-the-Market Reliance}

This super-causation argument suggests a misunderstanding of market efficiency and fraud-on-the-market reliance. ${ }^{160}$ In an efficient market, prices reflect all relevant available information, which certainly includes a corporation's most recent financial statements. ${ }^{161}$ If one engages in a fraud that provides the basis for creating fraudulent financial statements, that certainly violates the plain language of both $\S 10(\mathrm{~b})$ and Rule $10 \mathrm{~b}-5$. $^{162}$ The argument that since Merrill did not actually write the financial statements or disseminate them and therefore cannot have any liability to injured investors strains standard legal reasoning in torts, contracts, and criminal law. ${ }^{163}$

The text of Rule $10 \mathrm{~b}-5$ states that:

It shall be unlawful for any person, directly or indirectly, by the use of any means or instrumentality of interstate commerce. . . :

a) to employ any device, scheme, or artifice to defraud,

$\ldots$ or

c) to engage in any act, practice, or course of business which operates or would operate as a fraud or deceit upon any person, in connection with the purchase or sale of any security.

159. Id. at 385-86.

160. See Klock, supra note 14, at 325-27 (explaining the connection between fraud in transactions upon which financial reports are based and market prices).

161. See, e.g., Mark Klock, Are Wastefulness and Flamboyance Really Virtues? Use and Abuse of Economic Analysis, 71 U. CIN. L. REV. 181, 198 (2002) ("The most prevalent definition of market efficiency is that prices quickly and fully incorporate all available information.").

162. See Stoneridge Inv. Partners, LLC v. Scientific-Atlanta, Inc., 552 U.S. 148, 167 (2008) (Stevens, J., dissenting) (stating that the fraud was prohibited as a "deceptive device" under the statute); see also Klock, supra note 14, at 323-24 (stating that the fraud is prohibited under the plain language of the statute).

163. See generally Klock, supra note 14, at 322-30 (discussing problems with the Court's reasoning and understanding of financial markets and the economy).

164. 17 C.F.R. $\S 240.10 b-5$ (2009). 
Additionally, it must be observed that the authority for the creation of Rule $10 \mathrm{~b}-5$ is $\S 10(\mathrm{~b})$, which makes it unlawful to use any means of interstate commerce directly or indirectly:

To use or employ, in connection with the purchase or sale of any security registered on a national securities exchange or any security not so registered, any manipulative or deceptive device or contrivance in contravention of such rules and regulations as the Commission may prescribe as necessary or appropriate in the public interest for the protection of investors. ${ }^{165}$

The conduct of entities such as Merrill Lynch in the Nigerian Barge transaction with Enron, or Motorola in its fraudulent documentation of wash transactions with Charter Communications clearly falls within the plain language of terms such as scheme to defraud or operating a deceit upon a person. ${ }^{166}$ Even Central Bank's failure to update an outdated appraisal could reasonably be construed to be a "course of business which operates ... as a fraud. ..."167 The potential weakness in claims against such actors is the language, "in connection with the purchase or sale." The Court has limited this language. For example, in Merrill Lynch $v$. Shadi Dabit, ${ }^{168}$ the Court stated that the fraud must coincide with a securities transaction. ${ }^{169}$ In Stoneridge, the Court denied recovery because the fraud took place in the market for goods and services and not in the market for securities. ${ }^{170}$

This distinction between the market for goods and services and the market for securities has no foundation in economic reality and is inconsistent with both old and more recent Supreme Court decisions. ${ }^{171}$ The economic reality is that the price of securities transacted in the public market is based on the fundamental value that investors see in future profits, which is based on publicly available information about the corporation's level of business, customer base, and similar factors. ${ }^{172}$

165. Securities Exchange Act of 1934 \& 10(b), 15 U.S.C. $\S 78 \mathrm{j}(2009)$.

166. See, e.g., Klock, supra note 14, at 323-24 (discussing why the fraudulent acts fall within the plain language of the prohibition).

167. 17 C.F.R. $\$ 240.10 \mathrm{~b}-5$ (c). See, e.g., Klock, supra note 14, at 319 ("Although Central Bank did not actively participate in the fraud, its conduct could be found to be reckless and the Tenth Circuit Court of Appeals held that Central Bank could be liable....").

168. Merrill Lynch v. Shadi Dabit, 547 U.S. 71 (2006).

169. Id. at 85 .

170. Stoneridge Inv. Partners, LLC v. Scientific-Atlanta, Inc., 552 U.S. 148, 166-67 (2008).

171. See generally Prentice, supra note 6, at 615-76 (describing inconsistencies in the Court's decisions regarding liability for participating in securities fraud).

172. See LaWrence E. Mitchell et al., Corporate FinanCe and Governance $142-48$ (3d ed. 2006) (describing the valuation of stock and explaining the effects of alternative growth rates and the difficulty in estimating future growth); BURTON G. 
Fraud in the market for goods and services introduces misinformation in the securities markets and thereby affects the prices in securities transactions coincidentally with the fraud. ${ }^{173}$ In Basic v. Levinson, ${ }^{174}$ the Court adopted the fraud-on-the-market theory whereby plaintiffs could prove reliance on the misrepresentations based on the fact that the fraudulent information was disseminated in the market, and in an efficient market the market price incorporates all information. ${ }^{175}$ Therefore, the prices at which securities transactions are occurring are influenced by the misinformation that was introduced into the market. The Court's Stoneridge argument that fraud occurring in the product market is too remote to affect security prices ignores the economic reality that liquid financial markets rapidly incorporate information about economic activity in the product market. ${ }^{176}$

The fraud on the market theory was again upheld more recently in the 1997 decision U.S. v. O'Hagan. ${ }^{177}$ O'Hagan was a partner in a law firm representing a client corporation about to make a tender offer for another corporation. ${ }^{178}$ O'Hagan used the inside information to purchase shares and call options on more shares in the target before the information was public and he profited by more than four million dollars. ${ }^{179}$ The SEC then brought charges for violation of $\S 10(\mathrm{~b}) .^{180}$ The controversy around the case was ostensibly about the viability of the misappropriation theory whereby the exploitation of confidential information belonging to someone to whom a duty is owed is a basis for liability. ${ }^{181}$ The Court held that it is, but in doing so it effectively

MaLkeIl, A RANDOM Walk Down Wall Street 96-103 (7th ed. 1999) (describing the fundamental determinants of stock prices).

173. Klock, supra note 14 , at 326-27.

174. Basic Inc. v. Levinson, 485 U.S. 224 (1988).

175. Id. at $246-47$.

176. See Ivo WELCH, CoRPORATE FINANCE 350 (2009) ("Almost all financial economists, regardless of camp, believe in basic market efficiency for large markets and liquid securities. No respectable economist believes that it is easy to get very rich trading on easily available information.").

177. Specifically, the Court implied that investors are entitled to rely on the accuracy of the market price as incorporating all public information because insiders trading illegally on material private information are committing a fraud. See United States v. O'Hagan, 521 U.S. 642, 656 (1997) ("A misappropriator who trades on the basis of material, nonpublic information, in short, gains his advantageous market position through deception; he deceives the source of the information and simultaneously harms members of the investing public.").

178. Id. at 647 .

179. Id. at $647-48$.

180. Id. at 648 .

181. See, e.g., Carol B. Swanson, Reinventing Insider Trading: The Supreme Court Misappropriates The Misappropriation Theory, 32 WAKE FOREST L. REV. 1157, 1157-59 (1997) (summarizing controversy around O'Hagan and misappropriation theory). 
affirmed the fraud-on-the-market theory. ${ }^{182}$ The price for which the defendant bought the securities was based on the market valuation of all publicly available information. ${ }^{183}$ The defendant's use of confidential private information that he had obtained from a client of the firm gave him an unfair advantage and constituted a fraud on the market since participants in the market would not knowingly trade against investors with such an informational advantage. ${ }^{184}$

\section{Participating in Fraud Establishes a Duty}

The Court has repeatedly held that to be liable for fraud there must be a breach of duty. ${ }^{185}$ In Chiarella $v$. United States, ${ }^{186}$ the Court held that liability based on $\S 10$ (b) must be based on breach of a duty and that duty arises from a specific relationship between parties. ${ }^{187}$ The Court explained:

Section 10(b) is aptly described as a catchall provision, but what it catches must be fraud. When an allegation of fraud is based upon nondisclosure, there can be no fraud absent a duty to speak. We hold that a duty to disclose under $\S 10(\mathrm{~b})$ does not arise from the mere possession of nonpublic market information. ${ }^{188}$

The Court further limited the situations in which a defendant could be found to have breached a duty under $\S 10(\mathrm{~b})$ in the case of Dirks $v$. $S E C{ }^{189}$ The Court held that tippees trading on material and confidential inside information cannot be liable unless the tipsters are liable, and for the tipster to be liable there must have been an expectation of a personal benefit when conveying the information. ${ }^{190}$ Justice Powell wrote:

182. See O'Hagan, 521 U.S. at 653 ("The misappropriation theory is thus designed to "protect the integrity of the securities markets against abuses by "outsiders" to a corporation who have access to confidential information that will affect the corporation's security price when revealed ....'" (quoting Brief of the United States at 14, O'Hagan, 521 U.S. 642 (No. 96-842), 1997 WL 86306)).

183. See id. at 658-59 ("An investor's information disadvantage vis-à-vis a misappropriator with material, nonpublic information stems from contrivance, not luck; it is a disadvantage that cannot be overcome with research or skill.").

184. Id. at 659; see also Mark Klock, Mainstream Economics and the Case for Prohibiting Insider Trading, 10 GA. ST. U. L. REV. 297, 329-332 (1994) (explaining the economics underlying investors' refusal to knowingly trade against better informed investors).

185. See SteInBERG, supra note 11, at 861 (referencing Court decisions that assert that liability for violating $\S 10(\mathrm{~b})$ must be based on breach of a duty to disclose).

186. Chiarella v. United States, 445 U.S. 222 (1980).

187. Id. at 230 .

188. Id. at 234-35.

189. Dirks v. SEC, 463 U.S. 646, 657-58 (1983).

190. Id. at 661 . 
[A] tippee assumes a fiduciary duty to the shareholders of a corporation not to trade on material nonpublic information only when the insider has breached his fiduciary duty to the shareholders by disclosing the information to the tippee and the tippee knows or should know that there has been a breach. ${ }^{191}$

In Stoneridge the Court held that Motorola and the other defendants did not have a duty to the shareholders of Charter. ${ }^{192}$ Unfortunately, the Court only considered half of the theory of duty. ${ }^{193}$ The half the Court considered was duty created by relationship. The officers of Charter had a duty to the shareholders arising out of their agency relationship, and it is true that the officers of Motorola had no relationship with the shareholders of Charter that would give rise to a duty. However, duty can also be established by an affirmative act. ${ }^{194}$ An individual who pushes a small child into a deep pool has a duty to rescue him. ${ }^{195}$ Creating an appearance of real economic activity in wash transactions while falsely backdating documents to make the transactions appear independent is an affirmative act of fraud, even if in the goods and services market, that creates a duty to correct the misinformation introduced into the financial market. ${ }^{196}$

The erosion of investor protection under federal securities laws presents the possibility that more fraud actions will migrate to state court. ${ }^{197}$ Although the Uniform Standards Act of 1998 attempted to insulate corporations from securities class actions in state courts, the Delaware carve-out exception provided that investors are not prohibited from claims based on a breach of fiduciary duty. ${ }^{198}$ Providing shareholders misinformation even in the absence of a duty to disclose is a breach of fiduciary duty under Delaware law. ${ }^{199}$ Delaware law also recognizes aiding and abetting breaches of fiduciary duty. ${ }^{200}$ "Fragmented state protection in a national market is undesirable and

191. Id.

192. Stoneridge Inv. Partners, LLC v. Scientific-Atlanta, Inc., 552 U.S. 148, 159 (2008).

193. Cf. Klock, supra note 14, at 328 ("The Court also insincerely characterized the case as one involving lack of a duty of disclosure on the part of the vendors and customers of Charter.").

194. RESTATEMENT (SECOND) OF TORTS $\S 314 \mathrm{cmt}$. d (1965).

195. Id.

196. Cf. Mark Klock, Lighthouse or Hidden Reef? Navigating the Fiduciary Duty of Delaware Corporations' Directors in the Wake of Malone, 6 STAN. J. L. Bus. \& Fin., 1819 (2000) (discussing the duty not to deceive in the absence of a duty to disclose).

197. See, e.g., id. at 4.

198. See generally id. at 33-36 (discussing the "Delaware carve-out" exemption)

199. Malone v. Brincat, 722 A.2d 5, 14 (Del. 1998).

200. Id. at 15 . 
requires congressional action with leadership and support by the new President."201

\section{Removing Liability Removes Incentives for Ethical Behavior}

The decisions in Stoneridge and Regents of the University of California also are at odds with older decisions such as Herman \& MacLean v. Huddleston. In that decision, the plaintiffs had an express cause of action under $\S 11$ of the Securities Act for false information in a registration statement, but pleaded a cause of action for violation of $\S 10$ of the Securities Exchange Act. ${ }^{202}$ The Court allowed the action holding that:

[I]t is hardly a novel proposition that the Securities Exchange Act and the Securities Act "prohibit some of the same conduct."... In savings clauses included in the 1933 and 1934 Acts, Congress rejected the notion that the express remedies of the securities laws would preempt all other rights of action. ${ }^{203}$

The point of this passage is that at one time the Court held that a "cumulative construction of the securities laws ... furthers their broad remedial purpose." 204 However, without ever squarely addressing the inconsistency, the Court's more recent decisions have sought to restrict and limit private actions for securities fraud. ${ }^{205}$ It is an unlikely coincidence that subsequent to the rule set down in Central Bank we have witnessed an increase in securities fraud as measured by the number and magnitude of large financial scandals from Enron to Madoff and everything in between. ${ }^{206}$

Professor John Coffee constructed a careful historical analysis of the avalanche of financial scandals that hit our markets. ${ }^{207}$ He notes that most commentators attribute the wave to a decline in business morality,

201. Klock, supra note 14 , at 330 .

202. Herman \& MacLean v. Huddleston, 459 U.S. 375, 381-83 (1983).

203. Id. at 383 .

204. Id. at 386.

205. See, e.g., Murdock, supra note 17, at 134-36 (suggesting that the Supreme Court has strained legal reasoning to reach decisions that are biased in favor of corporate management).

206. See Coffee, supra note 9, at 288-290 (discussing how Central Bank contributed to a reduction in legal liability risk for accountants, corporate counsel, and underwriters and actually resulted in a dramatic drop in claims against them); Murdock, supra note 17, at 167 (linking the Central Bank decision to subsequent financial scandals involving accountants and lawyers).

207. See generally Coffee, supra note 9, at 269-309 (providing "a capsule social and economic history of the 1990 s" that led to the explosion of financial scandals in 20012002). 
but he observes that this is a somewhat circular explanation. ${ }^{208}$ Professor Coffee provides his own deeper analysis that attributes the scandals to many factors. ${ }^{209}$ Like an economist, Professor Coffee proclaims, "Perverse incentives, not declines in ethics, cause scandals." among Coffee's list of perverse incentives is the fact that corporate officers became more heavily compensated with corporate equity which incentivized officers to become more attentive to current stock price and less concerned with long-run performance. ${ }^{211}$ Although this shift in compensation could be a factor, I discount this explanation because current stock price is inherently an estimate of future performance. ${ }^{212}$ Professor Coffee also draws on the in vogue behavioral literature to suggest that investor biases in underestimating the probabilities of recessions played a role in pumping up market values and creating an environment where executives felt pressured to commit fraud to maintain prices. $^{213}$ Again, I discount this explanation because as much as the behavioralists would like to insist otherwise, cognitive biases cannot drive markets away from their fundamental values. ${ }^{214}$

The real culprit in the rise of the financial scandals is the removal of a credible deterrent to assisting in fraud. ${ }^{215}$ Central Bank declared that

208. Id. at 269-70.

209. See id. at 271-78 (attributing scandals to fundamental changes in corporate governance including the hostile takeover and changes in executive compensation which led to more aggressive earnings management).

210. Id. at 278 .

211. Professor Coffee suggests that:

Ironically, the principal actors who destabilized the existing corporate equilibrium were institutional investors and Congress. Institutional investors encouraged greater use of stock options to compensate both managers and directors in order to increase their sensitivity to the market. Congress unintentionally hastened this process by placing a ceiling on the cash compensation that senior executives could be paid.

Id. at 274 (footnote omitted).

212. See, e.g., Gordon J. AleXander et al., Fundamentals of InVestments 331 (3d ed. 2001) (equating the value of a stock to the discounted value of all future dividends that are expected to be paid).

213. See Coffee, supra note 9, at 293-95 (weaving a story of how the financial scandals could be a consequence of irrational markets, biased investors, and an atmosphere of euphoria).

214. See Mark Klock, Contrasting the Art of Economic Science with PseudoEconomic Nonsense: The Distinction Between Reasonable Assumptions and Ridiculous Assumptions, 37 PEPP. L. REv. 153, 199-202 (2010) (explaining that three basic assumptions about market structure-market clearing, budget constraints, and limited credit-ties the behavior of asset prices to their fundamental values independent of assumptions about investors cognitive abilities).

215. See, e.g., Klock, supra note 14, at 352-53 (blaming the poor economy on the pervasiveness of fraud in the markets as the result of a lack of market based incentives for ethical behavior). 
aiding and abetting securities fraud is not actionable. ${ }^{216}$ This meant that key gatekeepers of integrity had no incentive to disclose fraud, making it all the easier for officers to perpetuate and sustain fraud without being detected. $^{217}$ Although the Private Securities Litigation Reform Act made aiding and abetting fraud a violation, it made it one that could only be pursued by the SEC. ${ }^{218}$ However, the SEC's resources are severely limited and it cannot pursue all cases of aiding and abetting fraud. ${ }^{219}$ Furthermore, the Madoff scandal highlights the fact that the SEC is an institution that lacks the competence to detect fraud even when investigators have been presented with tips and detailed evidence. ${ }^{220}$ The position of sixteen former high-level SEC officials in their amicus curiae brief for the Stoneridge defendants further indicates that relying on the agency to act against aiders and abettors of fraud is a poor bet. ${ }^{221}$

Furthermore, the PSLRA erected major procedural obstacles to securities class actions further inhibiting private litigation. ${ }^{22}$ The Securities Litigation Uniform Standards Act also limited the ability of defrauded investors to pursue remedies in state courts. ${ }^{223}$ Additionally, in Stoneridge, the Court introduced a super-causation requirement that the fraud could not merely be a but-for proximate cause but needed to involve the actual security transaction or a direct communication to investors, as opposed to a misrepresentation to an auditor who then

216. Cent. Bank of Denver, N.A. v. First Interstate Bank of Denver, N.A., 511 U.S. $164,190-91$ (1994).

217. See Coffee, supra note 9, at 288-290 (describing the role of Central Bank in reducing the risk of gatekeepers being sued).

218. Stoneridge Inv. Partners, LLC v. Scientific-Atlanta, Inc., 552 U.S. 148, 158 (2008).

219. See Securities Investor Protection Act of 1991: Hearing Before the Subcomm. on Securities of the Senate Comm. on Banking, Housing and Urban Affairs, 102d Cong. 1516 (1991) (statement of SEC Chairman Richard C. Breeden) ("[T]he Commission does not have adequate resources to detect and prosecute all violations of the federal securities laws....").

220. See Klock, supra note 4, at 785 ("[T] scheme was afloat years earlier. . . . [T] investigations. . . ."); Rhee, supra note 4, at 375 ("For the SEC in this case, it could not detect fraud even though it was spelled out in explicit terms.").

221. See Brief for Former SEC Commissioners and Officials and Law and Finance Professors as Amicus Curiae Supporting Affirmance, Stoneridge, 522 U.S. 148 (2008) (No. 06-43), 2007 WL 2329639 (listing sixteen former SEC officials (three chairs, eleven commissioners, and two general counsels) arguing for the defendants and against the plaintiffs seeking recovery from participants in securities fraud).

222. See generally Branson, supra note 71, at 3-41 (describing the procedural hurdles created by the Private Securities Litigation Reform Act of 1995).

223. See generally Richard W. Painter, Responding to a False Alarm: Federal Preemption of State Securities Fraud Causes of Action, 84 CorNell L. REv. 1, 1-13, 3235 (1998) (describing the difficulties that plaintiffs in securities cases face after the Private Securities Litigation Reform Act of 1995 and Securities Litigation Uniform Standards Act of 1998). 
passes the misinformation along to investors. ${ }^{224}$ As Professor Prentice stated on Stoneridge, "the Court committed an anachronistic error comparable to a cowboy movie showing John Wayne listening to an iPod as he rides his horse across the Old West." ${ }^{, 25}$ Professor Prentice draws this analogy because the distinction between primary and secondary tort liability did not develop until a 1966 case, long after the securities laws were enacted. ${ }^{226}$ Under the law as it existed in 1934, the defendants in Stoneridge would have been considered joint tortfeasors subject to primary liability for their knowing participation in the scheme. ${ }^{227}$ Thus, classifying the defendants as secondary actors, for which Congress did not provide any liability, is an anachronistic error because there was no distinction between primary and secondary liability at the time the securities laws were enacted. ${ }^{228}$

The cumulative effect of all these developments has been to remove private enforcement as a deterrent and leave only the SEC. ${ }^{229}$ But given SEC resources, aiding fraud has become a winning bet with a no-lose outcome. ${ }^{230}$

224. See Stoneridge Inv. Partners, LLC v. Scientific-Atlanta, Inc., 552 U.S. 148, 16870 (2008) (Stevens, J., dissenting) (stating that the majority's super-causation requirement to establish reliance goes against the Court's earlier holding and discussing this point culminating in the conclusion that: "The Court's view of the causation required to demonstrate reliance is unwarranted and without precedent.").

225. Prentice, supra note 6 , at 612 .

226. Id. at 640 .

227. See id. at $643-44$ (explaining that the 1934 standard for liability was knowing participation in fraud).

228. Id.

229. Cf. Edward Labaton, The Gatekeepers are Still Accountable Even After Central Bank and the Contract with America, 38 ARIZ. L. REv. 547, 551 (1996) ("The [PSLRA] provides for no private right of action against aiders and abettors. It is difficult to understand a good faith rationale for that omission. Surely public policy should allow civil recovery against one who has aided and abetted a fraud.").

230. In a recent article I wrote:

$[F]$ raudsters know that they have a small probability of being subjected to enforcement actions by the SEC. They can hide in the vast market and take their chances on isolated enforcement actions by the Commission. If they are caught, they might have to disgorge their profits and pay a modest fine. If they are not caught and targeted, they will reap large rewards. The gamble seems like a pretty good one, especially for fraudsters who are likely to be much less risk adverse than the general population.

Klock, supra note 4, at 835. 


\section{A Caveat on Behavioralists' Proposals for Paternalistic REGULATION}

\section{A. Market Volatility Does Not Imply that Markets are Irrational or Inefficient}

A barrage of legal commentators has been bashing the efficient market hypothesis for the past ten years based on the argument that the volatility of the stock market demonstrates that markets are not rational and therefore not efficient. ${ }^{231}$ For example, Professors Geoffrey Miller and Gerald Rosenfeld argue that behavioral biases caused the financial crisis of 2008 and justify reforms of corporate governance, regulation and oversight, and even the education of "financial market personnel." Frank Partnoy argues that large movements in the stock market necessarily imply that the market is not efficient. ${ }^{233}$ Another illustrative example of bashing the assumption of rationality can be found in Jeremy Blumenthal's conclusion:

231. See, e.g., Lawrence A. Cunningham, Finance Theory and Accounting Fraud: Fantastic Futures versus Conservative Histories, 53 BuFf. L. REV. 789, 798 (2005) ("Behavioral finance theory undercuts modern finance theory and explains realities that modern finance theory cannot."); Erik F. Gerding, The Next Epidemic: Bubbles and the Growth and Decay of Securities Regulation, 38 CoNN. L. REv. 393, 395 (2006) ("According to behavioral finance theorists, stock market bubbles are driven by "noise traders' who make irrational investment decisions on the basis of herding behavior and behavioral biases."); Jeff Schwartz, Fairness, Utility and Market Risk, 89 OR. L. REv. 175,179 (2010) ("Behavioral finance scholarship has shown that the notion that share prices are correct rests on shaky theoretical and empirical underpinnings."); Peter Smith, New Legal Fictions, 95 GEO. L.J. 1435, 1456-57 (2007) ("Scholars have applied behavioral economics to investor behavior in particular, finding many examples of investor irrationality. In addition, scholars in the field of behavioral finance, a subdiscipline of behavioral economics, have produced significant evidence that markets are affected by the biases that affect individual behavior.") (citation omitted).

232. Geoffrey P. Miller \& Gerald Rosenfeld, An Economy In Crisis: Law, Policy, and Morality During the Recession: Article: 11. Theoretical Commentary: Intellectual Hazard: How Conceptual Biases in Complex Organizations Contributed to the Crisis of 2008, 33 HARV. J. L. \& PUB. POL'y 807, 840 (2010). Since these law professors do not provide a specific proposal, only a vague suggestion, there is no real substance to criticize in their proposal. However, the tone of the article raises an inference that these law professors are suggesting that lawyers should decide what theories and models finance professors can teach. Given that the perpetuation of the Madoff Ponzi scheme is a direct result of the failure of the legal curriculum to adequately educate lawyers in the field of finance, this seems to be a poorly thought out suggestion.

233. See Frank Partnoy, Why Markets Crash and What Law Can Do About It, 61 U. PITT. L. REV. 741, 751-52 (2000) ("It follows that the only possible explanation for large market movements (up or down) under the EMH is as a response to new information. However, the magnitude of market movements during times of crash is inconsistent with this explanation."); but see Klock, supra note 161, at 215-16 (criticizing this line of reasoning). 
There is little question that individuals do not conform well to the rational decisionmaker model posited by traditional law and economics. Our reasoning and decisionmaking about what is good for us is often flawed, our ability and motivation to seek full and unbiased information is often low, our susceptibility to manipulation by others is often high. These cognitive failings often serve us poorly, and legal and policy commentary has begun to turn toward consideration of what such failings imply about the propriety of thirdparty intervention to protect us from ourselves. ${ }^{234}$

The obvious point that is brushed under the table is that just because many decisions turn out to be regrettable mistakes is not evidence that the decisions were bad at the time they were made. ${ }^{235}$ Of course there are Darwin awards that are given to individuals that made obviously bad decisions. ${ }^{236}$ But this is the exception rather than the norm. ${ }^{237}$ Relatively few people achieve this status. ${ }^{238}$ The primary reason people make poor decisions in the present is that people are poor predictors of the future. ${ }^{239}$ However, there is certainly nothing irrational about our inability to

234. Jeremy A. Blumenthal, Emotional Paternalism, 35 FLA. ST. U. L. REv. 1, 70 (2007).

235. See Klock, supra note 161, at 232-33 (attributing mistakes to the difficulty in making long term forecasts); $c f$. Robert E. Hall, Struggling to Understand the Stock Market, 91 AM. ECON. REV. 1, 4 (2001). Professor Hall states:

Most suggestions of irrationality appear to deal with mistakes in probability rather than mistakes in marginal utility. ... In strictly stationary settings, the standard is straightforward for judging whether a person's subjective probability is correct. ... Rational beliefs about probabilities are only loosely constrained in a nonstationary world. An individual who believes that new principles govern the economy will not rationally use historical data to form beliefs about today and the future. Rather than deriving probabilities from past Id. experience, the individual will think through what will happen in the future.

236. See Wendy NorthCuTt, The Darwin Awards 4 at 3 (2007) ("Darwin Award winners plan and carry out disastrous schemes that a child can tell are a really bad idea.").

237. See id. at 5 ("The candidate must exhibit an astounding misapplication of judgment. We are not talking about common stupidities. ... The fatal act must be of such idiotic magnitude that we shake our heads. ...").

238. There were a mere ten posthumous recipients of Darwin Awards in 2010. 2010 Darwin Awards, DARWINAWARDS.COM, http://www.darwinawards.com/darwin/darwin 2010.html (last visited Sept. 17, 2011).

239. See Angela Littwin, Beyond Usury: $A$ Study of Credit-Card Use and Preference Among Low-Income Consumers, 86 TEx. L. REv. 451, 467 (2008) ("These terms refer to the finding that people tend to be poor predictors of their future preferences. Specifically, we habitually underestimate the intensity of our reactions to future costs and benefits."); Rick Swedloff \& Peter H. Huang, Tort Damages and the New Science of Happiness, 85 IND. L.J. 553, 575 (2010) ("Studies have shown that individuals are poor predictors of how life events-like winning the lottery or sustaining an injury-will change their overall life satisfaction and future affective states."). 
accurately predict what is unknown and unknowable. ${ }^{240}$ Nor is there anything irrational about taking a guess about what the future will be and making a decision based on that guess. ${ }^{241}$ When the guess turns out to be wrong, the decision will be revealed to be a mistake in hindsight, but it is not evidence that the decision was a bad one at the time it was made given what was unknown at that time. ${ }^{242}$

One notable voice in opposition to these behavioral law and economics and behavioral finance scholars has been Gregory Mitchell. Professor Mitchell is a lawyer who also has a Ph.D. in psychology. ${ }^{243} \mathrm{He}$ has written several articles demonstrating that the psychological research drawn on by behavioral law and economics commentators does not support the conclusions that they have drawn. ${ }^{244}$ According to Professor Mitchell, "Careful scrutiny of the psychological research reveals greater adherence to norms of rationality than that implied by the legal behavioralists, and the methodological and interpretive limitations on this psychological research make extrapolation from experimental settings to real world legal settings often inappropriate."245

240. See Burton G. Malkiel, A Random Walk Down Wall Street 106 (7th ed. 1999). Professor Malkiel explains:

$[\mathrm{T}]$ he mathematical precision of the firm-foundation value formulas is based on treacherous ground: forecasting the future. The major fundamentals for these calculations are never known with certainty; they are only relatively crude estimates - perhaps one should say guesses-about what might happen in the future.

Id.; $c f$. id. at 104 ("Precise figures cannot be calculated from undetermined data. It stands to reason that you can't obtain precise figures by using indefinite factors.").

241. Cf. BARRY SChwartZ, THE ParadoX OF ChOICE 198-99 (2004) (suggesting that agonizing over complex decisions creates stress and those who simply make a "good enough" choice rather than a best choice are happier).

242. Cf. John Allen Paulos, a Mathematician Reads the Newspaper 19 (1995) ("[P]olitical and economic matters ... are not very predictable....").

243. Gregory Mitchell, Taking Behaviorism Too Seriously? The Unwarranted Pessimism of the New Behavioral Analysis of Law, 43 WM. \& MARY L. REV. 1907, 1907 (2002).

244. See id at 1911 ("Unfortunately, the facile way in which these scholars summarize and then incorporate psychological research findings into legal theory ignores important limitations on this research."); Gregory Mitchell, Tendencies Versus Boundaries: Levels of Generality in Behavioral Law and Economics, 56 VAND. L. REV. 1781,1783 (2003) ("I contend that legal decision theorists have placed too great an emphasis on finding and describing behavioral tendencies toward irrationality, without due regard for the boundary conditions on these supposed tendencies."); Gregory Mitchell, Why Law and Economics' Perfect Rationality Should Not Be Traded for Behavioral Law and Economics' Equal Incompetence, 91 GEO. L.J. 67, 72 (2002) ("Behavioral law and economics bases its model of bounded rationality on a very limited set of empirical data and draws unsupportable conclusions about human nature from this partial data set.").

245. Mitchell, supra note 243, at 1907. 
There are simple fundamental economic reasons why financial markets are more volatile than in the 1950's. They relate to the nature of the economy. In the past, the bulk of the economy was involved in manufacturing and production of agricultural goods. ${ }^{246}$ The activity was capital intensive and utilized relatively unskilled labor. ${ }^{247}$ The manufacturing and agricultural sectors produced relatively predictable cash flows backed by physical capital and real property that could easily be seen and valued. ${ }^{248}$ The modern economy is heavily involved in services, intellectual capital, information, and other intangibles. ${ }^{249}$ It is difficult to see and value the assets of a firm working to unlock information in the genetic code. ${ }^{250}$ We cannot easily predict whether they will be successful in unlocking information, whether the information will be valuable, or whether they will be able to fully appropriate the value of that information for themselves. ${ }^{251}$ Since we cannot easily predict these outcomes, it is not unreasonable to expect our predictions to fluctuate widely. ${ }^{252}$

Likewise, a large segment of the value of many modern corporations lies in estimates regarding future growth rates. ${ }^{253}$ Cable and cellular company values depend on estimated growth in their customer base. ${ }^{254}$ Estimates of future growth are notoriously difficult to predict,

246. See, e.g., COUNCIL OF ECON. AdVISORS, ECONOMIC REPORT OF THE PRESIDENT 148 (1959) (showing that manufacturing and agriculture accounted for about $62 \%$ of GDP in 1958; the service sector accounted for only about $38 \%$ of GDP in 1958).

247. Cf. Victor R. Fuchs, The Determinants of the Redistribution of Manufacturing in the United States Since 1929, 44 REV. ECON. \& STAT. 167, 177 (1962) (attributing substantial components of manufacturing growth to an abundant supply of unskilled labor).

248. See Hall, supra note 235 , at 5 (explaining that the value of hard assets is stable and fluctuates little, and that postwar movements in financial claims are attributable to intangibles).

249. See id. at 6 ("In recent times and in technology-using industries, corporations have accumulated enormous stocks of intangible wealth, according to securities values.").

250. Cf. Hilary Shane \& Mark Klock, The Relation Between Patent Citations and Tobin's $Q$ in the Semiconductor Industry, 9 REV. QUANT. FN. \& ACCT. 131, 131 (1997) ("A firm's intangible assets ... are by their very nature more difficult to value.").

251. Cf. PAULos, supra note 242, at 158-59 (explaining that it is impossible to predict discoveries with any accuracy).

252. See Hall, supra note 235, at 11 ("Streams of future cash growing at high rates are hugely valuable. Growth rates of cash earned by companies exploiting new technologies have been phenomenal. The stock-market values of these companies swing wildly.").

253. See id. at 1 ("The stock market's movements are generally consistent with rational behavior by investors. ... [T] he key concepts are intangibles and their valuation based on the level and especially the growth of their cash flows.").

254. See Mark Klock \& Pamela Megna, Measuring and Valuing Intangible Capital in the Wireless Communications Industry, 40 Q. REV. ECON. \& FIN. 519, 530 (2000) (concluding that cellular communications companies stock values are statistically significantly affected by measures of installed customer base). 
and because of that they will fluctuate greatly. ${ }^{255}$ Additionally, many modern corporations derive a great deal of their value from embedded options in their business. ${ }^{256}$ This means that shares of stock in high technology companies with predominantly intellectual capital can behave more like options on stock than the plain vanilla equity that we saw decades ago. ${ }^{257}$ Anyone with a little understanding of modern financial markets knows that option prices are much more volatile than the prices of stocks for utility companies. ${ }^{258}$ A utility company is regulated, has a predictable customer base, and will generate steady cash flows without much growth. ${ }^{259}$ This type of cash flow is easily valued like a government bond, and the price of it will vary only a little as overall market rates of return on investments fluctuate. ${ }^{260}$

To further understand how markets with rational investors can be extremely volatile, and hence to understand that extreme volatility is not evidence of irrationality in the market, it is important to understand the concept of endogenous uncertainty. Investors' estimates of events that are to be determined in the future, such as growth rates in customer base, are influenced by their perceptions of what other investors' estimates are. $^{261}$ For example, suppose that John and Mary have the problem of liquidating some assets that have come into their possession from a recently deceased relative. One item is an old piece of furniture that Mary believes is not particularly valuable; however, some dealers and collectors take great interest in the item. Mary will naturally revise her beliefs given the new information that others appear to believe the item is valuable. Alternatively, there might be a collection of old coins in the

255. See MALKIEL, supra note 240, at 103-05 (describing the difficulty of forecasting long-term growth rates and the tendency for estimated growth rates to fluctuate between wild optimism and extreme pessimism).

256. See WELCH, supra note 176, at 417 ("Most corporate projects teem with embedded real options.").

257. See Mark Klock, Financial Options, Real Options, and Legal Options: Opting to Exploit Ourselves and What We Can Do About It, 55 ALA. L. Rev. 63, $72-74$ (2003) (describing the value of embedded options in businesses, especially technology).

258. See ALEXANDER ET AL., supra note 212, at 605 ("Options have become a popular type of investment because the potential returns from taking positions in options are much larger than those associated with long and short positions in the underlying asset.").

259. See Richard A. Brealey et al., Principles of Corporate Finance 66 (8th ed. 2006) ("Utilities are mature, stable companies which ought to offer tailor-made cases for application of the constant-growth DCF formula.").

260. Cf. Chárles J. Corrado \& Bradford D. Jordan, Fundamentals of INVESTMENTS $177-78$ ( $3 \mathrm{~d}$ ed. 2005) (illustrating the effect of a change in market interest rate on a simple security).

261. See Hall, supra note 235 , at 4 ("[O]ne person values another's opinion in assessing probabilities in a nonstationary environment."); Mark Rubinstein, Rational Markets: Yes or No? The Affirmative Case, 57 FIN. ANALYSTS J. 15, 23 (2001) (explaining the effect of endogenous uncertainty about others valuations on stock prices). 
estate that John believes is quite valuable; however, after soliciting bids from collectors and dealers John does not receive any offers. Again, John will naturally revise his belief about the value downward given the information that other knowledgeable people have no interest in the collection. This type of endogenous interaction between investors' beliefs about what other investors' estimates are for the future occurs constantly in the stock market and is capable of generating large swings in stock value even when all investors are perfectly rational. ${ }^{262}$

Some researchers have developed models that introduce irrational traders in the market and have obtained results that allow stock prices to diverge substantially from their true value for indefinite periods. ${ }^{263}$ Behavioralists have cited this research to support their argument that markets are not efficient. ${ }^{264}$ Unfortunately for the behavioralists, it has been demonstrated that these economic models that allow markets to escalate values well above their true worth in the presence of irrational investors are inherently flawed because all of them implicitly assume unlimited credit markets. ${ }^{265}$ When reasonable structural constraints are incorporated into a model of markets that ration credit and require budget constraints to be satisfied and supply to equal demand, then it is not possible for irrational investors to drive the aggregate market to an

262. See Hall, supra note 235, at 2, 10-11 (explaining that large swings in the value of Yahoo, eBay, and Amazon were rational changes in estimates of the future).

263. J. Bradford De Long et al., Noise Trader Risk in Financial Markets, 98 J. PoL. ECON. 703, 705 (1990) ("Because the unpredictability of noise traders' future opinions deters arbitrage, prices can diverge significantly from fundamental values even when there is no fundamental risk. . . . All the main results of our paper come from the observation that arbitrage does not eliminate the effects of noise....").

264. See, e.g., Frederick C. Dunbar \& Dana Heller, Fraud on the Market Meets Behavioral Finance, 31 DEL. J. CORP. L. 455, 53I (2006) ("Since the initial acceptance, criticism of the efficient market hypothesis has only grown larger. What began as a study of a few anomalies or instances where the theory did not perform well has grown to a well-developed aiternative school of thought that has both theoretical underpinnings and empirical research in its support."); Jill E. Fisch, Measuring Efficiency in Corporate Law: The Role of Shareholder Primacy, 31 J. CoRP. L. 637, 672 (2006) ("Stock price is a poor measure of firm value. Even in a market that is relatively informationally efficient, it is unlikely that market prices reflect fundamental value."); Erik F. Gerding, The Next Epidemic: Bubbles and the Growth and Decay of Securities Regulation, 38 ConN. L. REV. 393, 400 (2006) ("Behavioral finance draws upon extensive research in behavioral psychology and economics to demonstrate that investors do not act with perfect rationality. Moreover, behavioral finance has documented both statistical evidence of mispricings in securities. ..."); Ronald J. Gilson \& Reinier Kraakman, The Mechanisms of Market Efficiency Twenty Years Later: The Hindsight Bias, 28 J. CORP. L. 715, 717 (2003) (claiming that behavioral finance has displaced market efficiency); Troy A. Paredes, Blinded by the Light: Information Overload and It Consequences for Securities Regulation, 81 WASH. U. L. Q. 417, 483 (2003) ("Extensive studies show sustained mispricings and inefficiencies in capital markets. ...").

265. See generally Klock, supra note 214, at 198-202 (explaining the fallacy of the models which claim arbitrage does not eliminate the effects of noise traders). 
unsustainable level. ${ }^{266}$ To understand why unlimited credit is an unrealistic assumption, we need only observe the legal construct of limited liability. Because bankruptcy law ensures that liability will always be limited in fact, it is necessarily the case that credit will always be limited. ${ }^{267}$

The proof that market prices are constrained by the basic institutional features of market clearing, budget constraints, and limited credit without regard to investor rationality was developed by Professors Lowenstein and Willard. They write:

We argue that many properties of asset prices can be derived without reference to specific assumptions about investor rationality, given minimal and natural assumptions about limited asset liability, market clearing, and limited storage withdrawals. Our paper does not provide a defense for either investor rationality or nonrationality. . . . [I]f one believes that limited asset liability, market clearing, and limited storage withdrawals are reasonable economic assumptions, then one must regard the implied properties of asset prices as inviolable since they are independent of investor rationality.

The conclusions of this paper are built on the idea that certain economic principles limit the properties of asset prices independent of investor behavior, and that the limits implied by limited asset liability, market clearing, and limited withdrawals from the storage technology have been inadequately appreciated. Models that deviate from these assumptions risk offering misleading economic insights, no matter how tantalizing such insights may seem. ${ }^{268}$

Some stubborn readers might refuse to believe this and claim that the stock market value in 2007 was clearly too high and that the large drop in 2008 was completely predictable. The question such obstinate people need to answer is why did they not become billionaires given the predictability of the economic crisis? ${ }^{269}$ I believe that the answer is that in 2007 investors were forecasting positive economic growth and the valuations in 2007 were perfectly consistent with reasonable estimates of

266. See id. at 199 ("[B]asic principles of economics, such as limited liability, collateralized credit, and market clearing, restrict the properties of asset prices regardless of investors' behavior.").

267. Id. at 200.

268. Mark Lowenstein and Gregory A. Willard, The Limits of Investor Behavior, $61 \mathrm{~J}$. Fin. 231, at 232, 256 (2006).

269. Cf. Rubinstein, supra note 261 , at 21 (stating that the evidence that actively managed mutual funds run by smart professionals with vast resources and strong incentives cannot outperform passive mutual funds is a nuclear bomb that wins the debate over those claiming the stock market is predictable). 
future growth. ${ }^{270}$ In 2008 it became clear that the growth would not occur, and values accordingly dropped. But there was nothing predictable about the drop despite the fact that many people have twentytwenty hindsight. Another passage from Lowenstein and Willard's paper proving that all bubble models are inherently flawed aptly summarizes their results:

The economic intuition of our results is longstanding, clear, and compatible with more general neoclassical models of full rationality that are built on the same behavior-independent principles that we study. Simply put, investor behavior can be important for equilibrium asset prices, but only within certain limits that apply universally to all assumptions about investor behavior. ${ }^{271}$

In other words, investors' cognitive abilities are immaterial to the general neoclassical model of market equilibrium. ${ }^{272}$

There are two points to this digression on recent market volatility and market efficiency. One is that volatility is not evidence of inefficiency and we should not abandon legal doctrine that presumes that investors purchasing securities in a public market rely on the information in the market. ${ }^{273}$ The other point is that market drops are normal and natural occurrences that do not require heavy-handed paternalistic regulation to protect investors from themselves. ${ }^{274}$ Anti-fraud devices are good, but paternalism is not. ${ }^{275}$

What investors should have learned from the past several years is what finance professors have taught for decades. Diversify within asset classes, diversify across asset classes, and invest for the long-term. ${ }^{276}$

270. Cf. Hall, supra note 235, at 10-11 (explaining that the rapid appreciation in stock prices in the 1990's was consistent with the growth in cash flows, and the reversal in the appreciation in 2000 apparently coincided with diminished cash flow growth).

271. Lowenstein \& Willard, supra note 268, at 257.

272. Klock, supra note 214, at 199.

273. Cf. id. at 185-86 (suggesting that attacks on market efficiency from legal scholars are a threat to investor sovereignty and our system of securities regulation).

274. Cf. Christopher A. Stanley, The Panic Effect: Possible Unintended Consequences of the Temporary Bans on Short Selling Enacted During the 2008 Financial Crisis, 4 ENTREPREN. BuS. L.J. 277, 277-78 (2009) ("During almost every financial crisis in modern history, short sellers have been the recipients of blame, and regulators have attempted to limit the practice. This article argues that . . enacting hasty regulations on short selling during negative economic cycles will likely result in unintended, adverse consequences.") (footnote omitted).

275. See Mark Klock, Dead Hands-Poison Catalyst or Strength-Enhancing Megavitamin? An Analysis of the Benefits of Managerial Protection and the Detriments of Judicial Interference, 2001 COLUM. BUS. L. REV. 67, 126 (2001) (arguing that the government should require and enforce anti-fraud devices but not make decisions for investors).

276. See, e.g., Frank K. Reilly\& Edgar A. Norton, Investments 11 (7th ed. 2006) ("Diversify, Diversify, Diversify: Across Assets, Industries, and Even Countries."). 
Investors who held diversified portfolios and kept them intact, shifting fixed income investments to equity as the percentage of their portfolio invested in equity diminished came out of the crisis in good shape. ${ }^{277}$ Those who panicked and sold their stock as values declined and failed to keep the overall asset allocation balanced did not do well.

\section{B. Paternalistic Protection Creates Moral Hazard}

The dangers of paternalism have been extensively discussed by Professors Gregory Mitchell and Jonathan Klick. ${ }^{278}$ These commentators take note of the growing calls for government to protect people of normal intelligence from their decisions based on "research" that suggests that people of normal intelligence make the same bad decisions repeatedly. ${ }^{279}$ I place quotes around the phrase research in this context because elsewhere Professor Mitchell, who also holds a Ph.D. in psychology and a faculty appointment in that field, has criticized the behavioral law and economics scholars for improperly extrapolating results from limited and poorly controlled experiments in psychology and taking the results far out of context. ${ }^{280}$ In any case, the more recent point made by Mitchell and Klick is that even if we believe individuals make bad decisions and we have faith that our lives would be made better by a paternalistic government, there will be unintended and harmful consequences from such well-meaning protection. ${ }^{281}$

Specifically, restraints on behavior adversely affect individual development. ${ }^{282}$ Short-term protection has a negative effect on learning

277. Suppose that at the height of the market in October 2007 Jack had $\$ 100,000$ invested in stocks and $\$ 100,000$ in bonds. In February of 2009 that investment in stocks would have been worth only $\$ 50,000$, but the investment in bonds would have still been worth about $\$ 100,000$. If Jack rebalanced and sold $\$ 25,000$ in bonds to increase his portfolio investment in stocks back to $50 \%$ of the total allocation, the $\$ 75,000$ in stocks in February of 2009 would have appreciated to about $\$ 126,000$ by January 3, 2011. It would then be time to rebalance the other direction and sell some stocks to increase the proportion of the portfolio in bonds. The calculations are based on the level of the Dow Jones Industrial Average and the data was collected from YAHOO! FINANCE, http://finance.yahoo.com. The calculation also excludes the dividends that would have been collected and improved investment performance by even more.

278. Jonathan Klick \& Gregory Mitchell, Government Regulation of Irrationality: Moral and Cognitive Hazards, 90 MINN. L. REV. 1620 (2006).

279. See generally id. at 1620-1663 (analyzing numerous proposals to remove or limit free decision making from error prone citizens and the unintended consequences that are likely to result in ever worsening decision-making skills).

280. See Mitchell, supra note 244.

281. See Klick \& Mitchell, supra note 278 , at 1625 ("[W]e argue that there will often be long-run costs of patemalistic regulations that offset short-run gains because of the negative learning and motivational effects of paternalistic regulations.").

282. See id. at 1623 (" $[\mathrm{R}]$ estraints may adversely affect the development of individuality."). 
and motivation. $^{283}$ If individuals do not have to bear the consequences for their poor decisions, then they will have no incentive to make better decisions in the future and no reason to invest in learning from mistakes. ${ }^{284}$ Lawrence Mitchell and others have made similar arguments. $^{285}$

Mitchell and Klick build their argument using two bodies of research from the field of psychology that have been ignored by behavioralists advocating for more government protections. ${ }^{286}$ They succinctly summarize these:

First, research from developmental psychology indicates that individuals improve their decision-making skills over time through a "learning by doing" process, and that paternalistic policies threaten interference in this self-regulatory process. Second, research on selffulfilling prophecies warns that regulated parties are likely to become the weak decision makers envisioned by paternalistic policy makers, as paternalistic regulations undercut personal incentives to invest in cognitive capital and the regulated parties conform to the expectancies of the paternalist. ${ }^{287}$

These commentators later draw three propositions from the research:

(1) [P]aternalistic policies that restrict choice options restrict learning opportunities; (2) the noisier the learning environment, the more difficult to learn, and paternalistic policies introduce noise into, or mute feedback signals in, the learning environment; (3) the more extensive the paternalism imposed on citizens, the greater the cognitive hazard, due to restricted learning opportunities and more noise in learning environments. ${ }^{288}$

In the terminology of economics, paternalism creates a moral hazard whereby incentives to behave appropriately are removed and

283. See id. at 1636 (" $[\mathrm{R}]$ emoving incentives to make good decisions may negatively impact activity levels and the amount of cognitive resources invested in activities....").

284. See id. ("Indeed, learning may be greatest in response to negative or unfavorable outcomes.").

285. See Lawrence E. Mitchell, Cooperation and Constraint in the Modern Corporation: An Inquiry into the Causes of Corporate Immorality, 73 TEX L. REv. 477, 479 (1995) ("The constraining power of the state thus denies the context for full moral personhood on the part of corporate actors and consequently relieves them of moral responsibility for their actions on the corporation's behalf."); Klock, supra note 275, at 144 (asserting that protecting investors from their own bad judgment will inhibit responsible investing and even encourage excessive risk taking); John Stuart Mill, On Liberty (1859), in ON LIBERTY AND OTHER ESSAYS 1, 70 (John Gray ed., 1991) (arguing broad restraints on behavior will impede the development of individuality).

286. See Klick \& Mitchell, supra note 278, at 1626-27 (tying their work to research from developmental psychology and research on self-fulfilling prophecies).

287. Id.

288. Id. at 1633 . 
subverted with incentives to behave inappropriately. ${ }^{289}$ The classic examples of this effect in the economics literature are in the insurance market, where insured individuals are less likely to use reasonable care or accurately report the cause of an insured loss. ${ }^{290}$ Conflicts of interest arise whenever incentives diverge. Conflicts of interest are particularly acute in the case of insurance contracts where an insured party would like to collect a payoff and an insurance company would like to exclude a loss from coverage. ${ }^{291}$ But conflicts of interest occur in more subtle places, such as those occurring between managers and shareholders who both want to maximize their wealth and these conflicting objectives might require a different set of actions. ${ }^{292}$ Markets can develop some solutions to mitigate conflicts of interest. ${ }^{293}$ Monitoring, bonding, deductibles, and copayments are examples. ${ }^{294}$ Allowing markets to develop solutions can be more effective than regulation. ${ }^{295}$

A great irony underlying the arguments of those who favor heavyhanded paternalistic regulation is that they highlight managerial incentives to put their self-interest ahead of investors' interests, but they deny the power of incentives for investors to act in their own interests. Holding investors accountable for their own decisions, made in the absence of fraud, is the best way to promote investor welfare, market integrity, and economic growth and prosperity. ${ }^{296}$

\section{THE MAdOFF SCANDAL EXPOSES LIMITATIONS OF REGULATORS}

Over a period of about twenty years, Bernard L. Madoff ran a Ponzi scheme that owed about sixty billion dollars at the time of the 2008

289. Id. at 1644 .

290. KENNETH J. ARROw, The Organization of Economic Activity: Issues Pertinent to the Choice of Market Versus Nonmarket Allocation, reprinted in 2 COLLECTED PAPERS OF KENNETH J. ARROW 143 (1983).

291. Id.

292. See MiTCHELl ET AL., supra note 172, at 3-4 (describing some conflicts of interest innately embedded within corporations).

293. See Frederic S. Mishkin \& Stanley G. Eakins, Financial Markets \& INSTITUTIONS 406-09 (6th ed. 2009) (describing ways that markets respond to limit the effects of conflicts of interest).

294. Id. at $381,564$.

295. See Klock, supra note 10, at 100-01 ("The theory of regulation is based in economics rather than morality. .. . A general conclusion in [the] literature is that regulation that attempts to superimpose values is ineffective, or worse yet, counterproductive."); $c f$. FRANK H. EASTERBROOK \& DANIEL R. Fischel, ThE ECONOMIC STRUCTURE OF CORPORATE LAW 303 (1991) ("Regulation is more failure-prone than markets, because there are few automatic forces that correct regulation gone awry.").

296. See Klock, supra note 10, at 77 (discussing how policing fraud and requiring full disclosure has served the investing public well, and the lack of empirical data that regulators can outperform investors in decision making); cf. Klock, supra note 275, at 127 ("[P]rotection creates long-run detrimental incentive and behavior problems."). 
financial crisis which exposed the scheme. ${ }^{297}$ During this time Madoff operated in plain view of the SEC. The SEC even investigated Madoff several times based on tips from people in the industry, and on many occasions Madoff gave SEC investigators conflicting and ridiculous explanations for his activity that no one with a minimally competent performance in a rudimentary finance and investments class would have believed. ${ }^{298}$ Professor Robert Rhee called this "[ $t$ ]he most scandalous malfeasance of this new era. ..."299 Professor Rhee further explains "how a deficit in competence and training of lawyer regulators contributed to market regulatory failure." ${ }^{, 300}$ In this section, I will review some of the most outlandish errors committed by the lawyer regulators in dealing with Madoff. The intent here is to demonstrate that lawyer regulators receiving the current U.S. legal curriculum training not only lack the education and experience required for regulating the commercial world well, they also lack the appropriate incentives.

The SEC had several opportunities to expose Madoff before he surrendered to authorities on December 10, 2008, which could have potentially saved investors billions of dollars. ${ }^{301}$ The first golden

297. See Grant McCool \& Martha Graybow, Madoff Pleads Guilty, Is Jailed for \$65 Billion Fraud, REUTERS, Mar. 13, 2009, available at http://www.reuters.com/article/ idUSTRE52A5JK20090313 ("[P]rosecutors have said it amounted to as much as $\$ 65$ billion over 20 years and involved more than 4,800 client accounts.").

298. See generally Klock, supra note 4, at 788-808 (elaborating on details of the SEC's numerous missteps in investigating Madoff).

299. Rhee, supra note 4 , at 363.

300. Id.

301. See fTI Consulting \& U.S. Sec. \& ExCh. Comm'N, Office Of Inspector GENERAL, REPORT NO. 468, REVIEW AND ANALYSIS OF OCIE EXAMINATIONS OF BERNARD L. MADOFF INVESTMENT SECURITIES, LLC at ii (Sept. 29, 2009) available at http://www.sec-oig.gov/Reports/AuditsInspections/2009/468.pdf [hereinafter FTI, REVIEW OF OCIE EXAMINATIONS] ("The FTI Engagement Team found that OCIE examiners made critical mistakes in nearly every aspect of their examinations of Madoff and BMIS and missed significant opportunities to uncover Madoff's Ponzi scheme. The FTI Engagement Team concluded that OCIE examiners did not properly plan or conduct their examinations of Madoff. ...'); OIG, INVESTIGATION OF MADOFF, supra note 7, at 457. The OIG report stated:

The OIG found that the conduct of the examinations and investigations was similar in that they were generally conducted by inexperienced personnel, not planned adequately, and were too limited in scope. While examiners and investigators discovered suspicious information and evidence and caught Madoff in contradictions and inconsistencies, they either disregarded these concerns or relied inappropriately upon Madoff's representations and documentation in dismissing them. Further, the SEC examiners and investigators failed to understand the complexities of Madoff's trading and the Id. importance of verifying his returns with independent third-parties. 
opportunity occurred in $1992 .^{302}$ Tipsters to the SEC reported that two south Florida accountants named Avellino and Bienes were selling unregistered securities. ${ }^{303}$ Avellino and Bienes were soliciting sales for unregistered securities with written guarantees of zero risk and guaranteed returns ranging from $13.5 \%$ to $20 \%{ }^{304}$ Avellino and Bienes had been selling these securities for more than a decade and had collected $\$ 440$ million from investors. ${ }^{305}$ When the SEC investigated Avellino and Bienes seeking to recover investors' funds, they were told that all of the money had been invested with Madoff. ${ }^{306}$ SEC officials contacted Madoff and asked for help in returning the money. ${ }^{307}$ The next day, Madoff turned over $\$ 440$ million. ${ }^{308}$

This event should have sounded several alarms. The first principle of finance is that due to intense competition to make profits, higher returns can only be obtained by taking higher risks. ${ }^{309}$ Arbitrage cannot persist and zero risk investments must earn the riskless rate of return in equilibrium. ${ }^{310}$ Although arbitrage opportunities can occur, the competition in the market eliminates them quickly. ${ }^{311}$ When stock index arbitrage first developed in the early 1980's, arbitrage opportunities would be eliminated typically within forty-five minutes. ${ }^{312}$ The subsequent reduction in trading costs and the subsequent improvements

302. See OIG, INVESTIGATION OF MADOFF, supra note 7, at 61 ("[A]ssuming that Bernard Madoff was running his Ponzi scheme in 1992, the SEC missed an excellent opportunity to uncover this scheme by not undertaking a more thorough and comprehensive investigation.") (footnote omitted containing facts suggesting that Madoff's Ponzi scheme was running in 1992).

303. See Randall Smith, Wall Street Mystery Features a Big Board Rival, WaLL ST. J., Dec. 16, 1992, at C1 ("The Securities and Exchange Commission recently cracked down on one of the largest-ever sales of unregistered securities. Investors had poured $\$ 440$ million into investment pools raised by two Florida accountants, who for more than a decade took in money without telling the SEC....").

304. Id.

305. $I d$.

306. OIG, INVESTIGATION OF MADOFF, supra note 7, at 46.

307. Id. at 53 (reporting New York Enforcement Staff attorney's recollection about approaching Madoff for the return of investors' funds).

308. Id. ("[Madoff] was able indeed to liquidate the investments and get the cash available within a very short period of time. ...").

309. See MALKIEL, supra note 240, at 220-21 (1999) ("As every reader should know by now, risk has its rewards. ... Thus, to get a higher average long-run rate of return in a portfolio, you need to increase the risk level of the portfolio. ...").

310. See generally WELCH, supra note 176, at 360-63 (defining and explaining arbitrage).

311. See id. at 362 ("True arbitrage opportunities are difficult or outright impossible to find in the real world, especially in very competitive financial markets.").

312. Cf. ZVI BODIE ET AL., ESSENTIALS OF INVESTMENTS 587 (5th ed. 2004) (describing how the arbitrage only works if many securities can be traded simultaneously because the opportunities are short-lived, and hence require programs to send multiple orders directly to the exchange floor over computer lines). 
in communications and data processing caused these opportunities to disappear even more quickly. ${ }^{313}$ The idea that someone could consistently generate high returns at no risk over a long period is no more credible than the idea that a single Santa Claus can deliver presents to every house around the world in a single night.

Additionally, the second principal of finance is that liquid investments (investments that can be converted to cash quickly and cheaply) provide an even lower return. ${ }^{314}$ The fact that Madoff liquidated the high yield investments for full value in a single day was another alarm that was set off, but ignored. The obvious question that SEC investigators should have asked Madoff in 1992 was, where did he get the $\$ 440$ million from in a day $?^{315}$ Astonishingly, no one asked the question. ${ }^{316}$

After dodging that bullet, Madoff's Ponzi scheme continued to operate under the radar until 2000 when a competing financial analyst named Harry Markopolis began trying to get the SEC to investigate Madoff. $^{317}$ In 2001, Barron's reported that many people in the industry were skeptical and believed that Madoff could not be doing what he claimed to do. ${ }^{318}$ These events should have triggered investigation by the SEC, but did not. ${ }^{319}$ Not until several more detailed complaints came in did the SEC commence another investigation with the potential to uncover the Ponzi scheme. ${ }^{320}$ Between 2004 and 2008, several investigations were opened and closed without uncovering the Ponzi scheme, notwithstanding complaints and tips received detailing the facts that indicated Madoff had to be running a Ponzi scheme. ${ }^{321}$ These

313. See David E. Sanger, Market Turmoil; Program Trading Curb Now Widely Expected, N.Y. TIMES, Oct. 26, 1987, at D1 ("[C]omputers have tightened the links between the two markets, assuring that when one moves, the other moves with it.") (interviewing Louis Margolis, Managing Director, Salomon Bros.).

314. See ZVI BODIE ET AL., INVESTMENTS 267 (4th ed. 1999) ("Investors prefer more liquid assets with lower transaction costs, so it should not surprise us to find that all else equal, relatively illiquid assets trade at lower prices or, equivalently, that the expected return on illiquid assets must be higher.").

315. OIG, INVESTIGATION OF MADOFF, supra note 7 , at 26 (stating that an investigation into the source of the money would have been "common sense").

316. See id. at 61 (" $[\mathrm{N}]$ o investigative actions were taken to determine if the funds that Avellino \& Bienes arranged to have repaid were taken from other customers as part of a larger Ponzi scheme engineered by Bernard Madoff.").

317. OIG, INVESTIGATION OF MADOFF, supra note 7, at 61.

318. Id. at 75-76 (citing Erin Arvelund, Don't Ask, Don't Tell, Barron's, May 7, 2001 , at 26).

319. Id. at 76-77.

320. See Klock, supra note 4, at 794 (stating that an investigation was not conducted until 2004 after receiving additional complaints).

321. See generally OIG, INVESTIGATION OF MADOFF, supra note 7, at 31-41 (chronicling the investigations and tips during this period). 
investigations focused on mundane minor technical violations. For example, there was some focus on whether Madoff was giving investment advice when he was not registered as an investment advisor. $^{322}$ Also, there was some focus on whether Madoff was frontrunning his customers even though the complaints about Madoff did not allege front-running. ${ }^{323}$ Front-running occurs when a broker executes trades for his own account in front of the trades he executes for his clients, for his advantage and for the clients' disadvantage. ${ }^{324}$ The explanation given by the SEC enforcement staff for focusing on frontrunning was that the lawyers running the investigation only had experience dealing with front-running. ${ }^{325}$

In fact, the complaints alleged much more serious charges, and were supported with facts and analysis that did not receive competent investigation. One issue raised pertained to Madoff's business model, which purported to abandon management fees that Madoff could have earned amounting to billions of dollars, and instead paid that money out to feeder funds, which channeled investor money to Madoff. ${ }^{326}$ In order for the business model to work, not only would Madoff need to irrationally abandon that money for himself, but he had to generate an additional four percent above what he was promising investors. ${ }^{327}$ Madoff also suspiciously claimed to be earning high returns consistently-even during recession periods-without taking risks. ${ }^{328}$ He claimed to be doing this by hedging his positions in the options market, but the strategy did not make sense financially and, more significantly, the volume of trading required to support this hedging did not exist on the options exchange. ${ }^{329}$

When Madoff was asked about the lack of volume on the options exchange he asserted that he traded options over-the-counter after hours

322. See id. at 37 ("[M]ost of the Enforcement staff's efforts during their investigation were directed at determining whether Madoff should register as an investment adviser. ...').

323. FTI, REVIEW OF OCIE EXAMNATIONS, supra note 301, at 6.

324. Id. at n.4.

325. See id. at 11 ("OCIE management indicated that the Market Oversight/SRO group decided to focus on front-running during the cause examination because that was the group's area of expertise.").

326. Michael Ocrant, Madoff Tops Charts: Skeptics Ask How, MAR/HEDGE, May 2001, at 3, available at http://nakedshorts.typepad.com/files/madoff.pdf ("[E]xperts ask ... why Madoff Securities is willing to earn commissions off the trades but not set up a separate asset management division to offer hedge funds directly to investors and keep all the incentive fees for itself. ...").

327. Rhee, supra note 4, at 367-68.

328. See OIG, INVESTIGATION OF MADOFF, supra note 7, at 21, 22, 27-28 (describing the impossibility of Madoff's claimed returns).

329. Rhee, supra note 4, at 368. 
in Europe. ${ }^{330}$ The claim was preposterous, but was accepted by the investigators without verification. ${ }^{331}$ Amazingly, when the scandal came out and the investigators were interviewed, they claimed that they never attempted to verify Madoff's conflicting and contradictory explanations with third parties. ${ }^{332}$ Apparently, they did not consider verification to be part of the job of conducting an investigation. Such a response displays a lack of competence that is much broader than merely not understanding derivative financial instruments.

Madoff also provided computer printouts of positions he held, but investigators never attempted to verify those positions with third parties, such as the clearing corporation. ${ }^{333}$ The clearing corporation clears and settles all transactions in publicly traded securities and maintains data on the trades. ${ }^{334}$ The SEC has access to the data and uses it to trigger investigations in cases involving possible insider trading, such as former New York Congressman Rick Lazio. ${ }^{335}$ Any effort to verify Madoff's statements would have revealed that they were fraudulent. ${ }^{336}$

Apparently, in order to avoid some financial reporting, Madoff also made the remarkable claim at one point to not hold securities at the close of each month because he converted all of his positions to cash at the end of each month. ${ }^{337}$ The transactions costs and tax consequences of such a strategy would make it less profitable and therefore implausible. ${ }^{338}$ This should have sounded another alarm.

One other red flag that the SEC ignored was Madoff's auditor. ${ }^{339}$ Madoff was asked to produce audited financial statements and he produced audits purportedly done by David Friehling. ${ }^{340}$ But no one had

330. Cf. OIG, Investigation OF MADOFF, supra note 7, at 285 ("[T] staff was not suspicious of Madoff's claim to have had billions of dollars invested in undocumented OTC options contracts.").

331. Id. at 314.

332. See id. at 333 ("Bachenheimer ... testified that obtaining third-party verification was not an 'essential' part of a Ponzi scheme investigation. ...").

333. See id. at 39 (suggesting that "the most egregious failure" of the SEC staff was to not verify trade data).

334. FTI, REVIEW OF OCIE EXAMINATIONS, supra note 301, at 25.

335. See Clifford J. Levy and Floyd Norris, S.E.C. Investigating Lazio Trading In Securities of Donors' Company, N.Y. TIMES, June 23, 2000, at B 1 (stating that suspicious trading volume was noted in data from the Clearing Corporation).

336. OIG, INVESTIGATION OF MADOFF, supra note 7, at 40.

337. See id. at 80 ("[A]ccounts are typically in cash at month end.").

338. Klock, supra note 4, at 795 .

339. See FTI, REVIEW OF OCIE EXAMINATIONS, supra note 301 , at 37 ("Examinations did not adequately look into the allegations of the auditor's lack of independence or refer such allegations to the appropriate agency."); OIG, INVESTIGATION OF MADOFF, supra note 7 , at 419 (noting that the investment community was concerned about Madoff's auditor being small and unknown while Madoff was reportedly managing billions of dollars).

340. OIG, INVESTIGATION OF MADOFF, supra note 7, at 173-74. 
ever heard of David Friehling, and Friehling did not have the resources to conduct a competent audit of an operation as large as Bernard L. Madoff Securities, LLC. ${ }^{341}$ Indeed, Friehling had annually told the American Institute of Certified Public Accountants that he did not

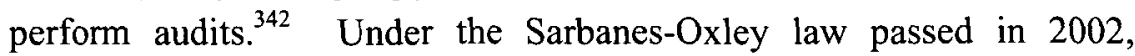
Friehling should have been required to be registered with the Public Company Accounting Oversight Board to conduct audits of a brokerage firm, but the SEC had issued a waiver for auditors of privately held firms. ${ }^{343}$ Still, the investigators should have been alerted by the insignificance of the audit firm. ${ }^{344}$ Indeed, once Madoff was arrested it took investigators visiting Friehling's office only a few hours to realize that no bona fide audit work had ever been done. ${ }^{345}$

In the words of Professor Rhee, "the SEC and its lawyers were presented the proverbial "videotape" of the [Madoff] crime, and yet they were unable to comprehend what had occurred because they lacked the skills, knowledge, and education."346 To make matters worse, the incompetent investigations of Madoff actually exacerbated the fraud because they gave outsiders some validation that Madoff was legitimate. ${ }^{347}$ Numerous investors testified that Madoff told them that he had been investigated and cleared by the SEC and that they had relied on the SEC's scrutiny of Madoff as evidence that his operation was legitimate. ${ }^{348}$

341. See id. at 419 (reporting that the unknown and small accounting business was a matter of concern to sophisticated investors); Reuters, Regulators Defend Madoff Oversight, N.Y. TIMES, Jan. 27, 2009, http://www.nytimes.com/2009/01/28/ business/28madoff.html? r $=1$ ("Mr. Dodd expressed disbelief that the S.E.C. did not zero in on the fact that Mr. Madoff's auditor was a tiny, little-known auditor. 'Isn't it often a preliminary questions to ask, who is your auditor?' said Mr. Dodd.").

342. See Complaint at 45 , S.E.C. v. Friehling (S.D.N.Y. Mar. 16, 2009) (No. 09 Civ. 2467) ("[A]nnually since 1994, Friehling falsely told the AICPA that he did not conduct audits."), available at http://www.sec.gov/news/press/2009/2009-60.htm (last visited Jan. 18, 2011).

343. See Floyd Norris, Audit Rule Is Revived By S.E.C., N.Y. TIMES, Jan. 9, 2009, at B5 ("Brokerage firms like Madoff Securities are required to be audited by firms that were registered with the Public Company Accounting Oversight Board, which was created under the Sarbanes-Oxley Act in 2002 [but Friehling was not registered because the SEC issued a waiver of the requirement for privately held firms].").

344. See Klock, supra note 4, at 816 ("For a financial player the size of Bernard L. Madoff Investment Securities, LLC to not use a large auditor should have generated immediate suspicion about the credibility of the audits.").

345. OIG, INVESTIGATION OF MADOFF, supra note 7, at $174 \mathrm{n} .107$.

346. Rhee, supra note 4 , at 377.

347. See OIG, INVESTIGATION OF MADOFF, supra note 7, at 25 ("[T] had conducted examinations and investigations and did not detect the fraud, lent credibility to Madoff's operations and had the effect of encouraging additional individuals and entities to invest with him.").

348. See id. ("[I]nvestors who may have been uncertain about whether to invest with Madoff were reassured by the fact that the SEC had investigated and/or examined 


\section{OptIMAL REgUlation SHOULd INCENTIVIZE ETHICS}

\section{A. A Problem with Paternalistic Regulators-Inability to Define the Public Good}

Improved training in law schools can improve the competence of financial regulators. ${ }^{349}$ Law schools could require training in statistical and economic reasoning and also educate students about the valuation of financial assets and the structure of financial markets. ${ }^{350}$ This should be done to improve the advice that lawyers give their clients. ${ }^{351}$ However, even improved training for law students is unlikely to lead to efficient paternalistic decision making for investors by regulators because the regulators will still lack the appropriate incentives. ${ }^{352}$

The desire to work for the public interest or the public good can be a strong incentive, but it is not as powerful as the incentive to work for one's own self-interest. $^{353}$ Investors, in the absence of paternalistic intervention, have a powerful incentive to invest in their own best interests, and are best able to determine what their own best interests are. ${ }^{354}$ They know whether they are saving to obtain a down payment for a house in two years or for retirement in 30 years. They know whether they favor conservative investments without risk or whether they have

Madoff ... and found no evidence of fraud. Moreover, we found that Madoff proactively informed potential investors that the SEC had examined his operations.").

349. See, e.g., Jose Gabilondo, Financial Moral Panic! Sarbanes-Oxley, Financier Folk Devils, and Off-Balance-Sheet Arrangements, 36 SETON HALL L. REV. 781, 850 (2006) ("I call on my transactional law colleagues to foster more integration of analytical financial methods into a basic legal education. Such an approach might produce more transactional lawyers capable of spotting and stemming future financial moral panics.").

350. Cf. Robert J. Rhee, The Socratic Method and the Mathematical Heuristic of George Pólya, 81 St. JoHN's L. Rev. 881, 882 n.5 (2007) ("In my classes, Torts, Business Associations, Corporate Finance, and Negotiations, basic mathematical intuitions arise more frequently than students prefer. Examples include complex causation, marginal costs, capital structure, asset valuation, expected value and probabilities, and basic intuitions of law and economics.").

351. See Thomas D. Morgan, Educating Lawyers for the Future Legal Profession, 30 OKLA. CITY U. L. REV. 537, 541 (2005) ("Clients of the future ... are even more likely to want their lawyers to resemble multi-disciplinary consultants rather than narrow legal technicians.").

352. See Klock, supra note 4, at 833 ("We can provide more training for SEC examiners and more rules and checklists for them to follow, but at the end of the day, a government employee does not have as strong an incentive to adequately police the market as private market participants have to protect their investments.").

353. Cf. EASTERBROOK \& FISCHEL, supra note 295, at 303 ("We have no desire to commit the . . . fallacy of asserting that if markets are 'imperfect' regulation must be better. . . Regulation is more failure prone than markets because ... the regulatory system lacks a competitor. ...").

354. See Klock, supra note 275 , at 126 ("Shareholders, not judges, are in the best position to decide [their best interests]."). 
the temperament and disposition to ride the volatility of the stock market. Regulators working for the public good have two problems to overcome that cannot be solved. First, the public good is not defined, and indeed it cannot be defined as has been demonstrated by Kenneth Arrow's wellknown impossibility theorem. ${ }^{355}$ Second, even the most fervent true believers working in regulatory agencies must concede that there are some workers in their agency who are merely there to collect a paycheck because it was the best job they could get in the location where they desire to reside. ${ }^{356}$ Such regulators have little incentive to work in the best interest of the public even if they could define it.

Arrow's impossibility theorem, referred to in the preceding paragraph, is a rigorous formal mathematical proof that it is impossible to construct a democratic voting scheme that will result in rational social preferences. ${ }^{357}$ Arrow's Theorem is also sometimes called the paradox of voting. ${ }^{358}$ The paradox is that election results need not map into social preferences and need not lead to a rational preference ordering. ${ }^{359}$ Professor Hal Varian gives an example in a popular microeconomics text. ${ }^{360}$ A bill before Congress in 1956 called for federal aid for school construction. ${ }^{361}$ One legislator introduced an amendment to the bill that would limit federal aid for school construction to states with integrated schools. ${ }^{362}$ There were three roughly equal sized groups in the House of Representatives. $^{363}$ Professor Varian describes how the procedural rules of voting on the amendment were first used to defeat a bill that originally had a majority of support:

355. See generally, Mark Klock, Is It "The Will of the People" or a Broken Arrow? Collective Preferences, Out-of-the-Money Options, Bush v. Gore, and Arguments for Quashing Post-Balloting Litigation Absent Specific Allegations of Fraud, 57 U. MIAMI L. REV. 1, 14-16 (2002) (explaining Arrow's Impossibility Theorem and Kenneth Arrow's contribution in proving the theorem).

356. See, e.g., William W. Bratton and Joseph A. McCahery, Regulatory Competition, Regulatory Capture, and Corporate Self-Regulation, 73 N.C. L. REV. 1861, 1878 (1995) ("N] ow regulators should be expected to behave no differently than actors in private economic relations.").

357. Kenneth J. Arrow, A Difficulty in the Concept of Social Welfare, 58 J. PoL. ECON. 328, (1950); see also Klock, supra note 355, at 15.

358. Klock, supra note 355 , at 15.

359. Id.

360. HAL R. VARIAN, INTERMEDIATE MiCROECOMICS 710 (8th ed. 2010). For a second example, see also PAULOS, supra note 242, at 104-06 (explaining that five reasonable but different methods of combining preferences at a hypothetical 1992 presidential election voting caucus could create five different winning candidates).

361. VARIAN, supra note 360 , at 710.

362. Id.

363. Id. 
- Republicans. They were opposed to Federal aid to education, but preferred the amended bill to the original. Their ranking of the alternatives was no bill, amended bill, original bill.

- Northern Democrats. They wanted Federal aid to education and supported integrated schools, so they ranked the alternatives amended bill, original bill, no bill.

- Southern Democrats. This group wanted Federal aid to education, but would not get any aid under the amended bill due to the segregated schools in the South. Their ranking was original bill, no bill, amended bill.

In the vote on the amendment, the Republicans and the Northern Democrats were in the majority, thereby substituting the amended bill for the original. In the vote on the amended bill, the Republicans and the Southern Democrats were in the majority, and the amended bill was defeated. However, before being amended the original bill had a majority of the votes! $!^{364}$

The paradox of voting was discovered in the $18^{\text {th }}$ century. ${ }^{365}$ It was forgotten and then rediscovered in the $19^{\text {th }}$ century by Lewis Carroll who observed that faculty votes at Oxford were logically inconsistent and highly sensitive to procedural rules. ${ }^{366}$ But the formal proof was never developed until Arrow worked it out in the $20^{\text {th }}$ century, and received a Nobel Prize for the work. ${ }^{367}$

According to Professor Laurence Tribe, the significance of Arrow's work is that it is impossible to construct the will of the people. ${ }^{368}$ The "public good" must be an even more elusive concept than the "will of the people" and if we cannot construct the later, surely we cannot divine the former. The inability of political processes and institutions to produce stable results suggests that it is not wise to use non-market interventions to "protect" market participants from their informed decisions, whatever cognitive biases they might have. ${ }^{369}$

364. Id at $710-11$.

365. Klock, supra note 355 , at 14.

366. IAIN MCLEAN, Public Choice: AN INTROdUCtion 10 (1987).

367. Klock, supra note 355, at 14.

368. See LaURENCE H. TRibe, American Constitutional LaW $\S 1-7$, at 12 n.6 (2d ed. 1988) (noting that Arrow's theorem suggests that there is no hope of meaningfully constructing majority will).

369. Cf. Michael Abramowicz and M. Todd Henderson, Prediction Markets for Corporate Governance, 82 NOTRE DAME L. REV. 1343, 1354 (2007) ("[S]tock markets appear nonetheless to be superior to alternative approaches to distributing capital, such as 


\section{B. Incentivizing Ethics Works Better than Micro-Management}

The period before 1933 is often portrayed as a time of caveat emptor in the financial markets. ${ }^{370}$ Although many states had laws on the books regulating the sale of securities, ${ }^{371}$ fraudsters could move from state to state and escape jurisdiction. The passage of the federal securities laws changed the world for the better by abandoning the philosophy of caveat emptor with a comprehensive plan to deter fraud by providing for strict liability for failure to disclose any material fact in the primary market, and for using any manipulative or deceptive device in the secondary market. ${ }^{372}$ However, Congress wisely stopped short of paternalistic regulation. ${ }^{373}$

At the time these laws were new, there was no distinction between fraudsters who were primarily liable and fraudsters who were secondarily liable. ${ }^{374}$ Anyone knowingly participating in the fraud would be liable. ${ }^{375}$ Legal developments during the previous two decades have reduced investor protection from fraud. ${ }^{376}$ As a result of changed incentives that immunize many participants in fraud from liability, we have witnessed an increase in shady gray unethical conduct, and blatant

assigning government officials or panels of experts to judging the future effectiveness of various companies.").

370. Dalia Tsuk Mitchell, Shareholders as Proxies: The Contours of Shareholder Democracy, 63 WASH. \& LEE L. REV. 1503, 1541 (2006).

371. See James D. Cox ET AL., Securities Regulation 14 (2004) ("At the time of the Great Crash, nearly all states embraced some form of regulation of brokers and securities.").

372. See Securities Act of $1933 \S 11,15$ U.S.C. $\S 77 \mathrm{k}$ (2006) (providing for strict liability for failure to disclose all material facts in the registration statement); Securities Exchange Act of $1934 \S 10(\mathrm{~b}), 15$ U.S.C. $\S 78 \mathrm{j}$ (2009) (prohibiting manipulative or deceptive devices in connections with the sale of a security).

373. See Klock, supra note 10, at 77 (stating that Congress rejected merit regulation for good reason).

374. Prentice, supra note 6, at 625.

375. Id. at 624 .

376. See Murdock, supra note 17, at 131. Professor Murdock begins his condemnation of judges and politicians for removing investor protections:

This article asserts that Congress and the federal courts are complicit in the widespread corporate corruption that has come to light this past decade. It begins by exploring the notion of bias and then chronicles judicial developments which have protected corporate officials, who have engaged in securities fraud and other wrongful conduct, at the expense of innocent shareholders and investors. It also analyzes the public policy in favor of corruption embodied in the Private Litigation Securities Reform Act, and the actions of federal courts in expanding the protection of PLSRA even beyond that dictated by the language of the statute. 
fraud. ${ }^{377}$ This in turn has led to calls for more heavy-handed regulation proposing more technical rules for accounting statements and limitations on investor choices. ${ }^{378}$ These proposals carry their own perverse consequences and are not necessary. ${ }^{379}$ All that is needed to restore confidence in the market is a return to the original intent and philosophy of federal securities laws that allows private causes of action to recover against all who substantially participate in securities fraud. ${ }^{380}$ Such a change by Congress would provide the appropriate incentives to foster a high level of ethical behavior in the financial sector. ${ }^{381}$

Well before the wave of accounting scandals hit, the SEC Chairman Arthur Levitt stated in a portion of a 1998 speech:

I fear that we are witnessing an erosion in the quality of earnings, and therefore, the quality of financial reporting. Managing may be giving way to manipulation; Integrity may be losing out to illusion.

Many in corporate America are just as frustrated and concerned about this trend as we, at the SEC, are. They know how difficult it is to hold the line on good practices when their competitors operate in the gray area between legitimacy and outright fraud.

A gray area where the accounting is being perverted; where managers are cutting corners; and, where earnings reports reflect the desires of management rather than the underlying financial performance of the company. ${ }^{382}$

377. See id. at 209 ("The theme of this article is that courts and legislatures, particularly Congress and the federal courts, led by the Supreme Court, have been complicit by creating an environment in which management is not called to account.").

378. See, e.g., Jill E. Fisch, Regulatory Responses to Investor Irrationality: The Case of the Research Analyst, 10 LEWIS \& CLARK L. REV. 57, 78 (2006) ("Regulators have taken several steps to address irrational investor trading in reliance on tainted or biased analyst recommendations. Overall, the approach has evolved from one of disclosure and investor education to an increasing degree of paternalism.").

379. See Klick and Mitchell, supra note 278, at 1661 ("[G]overnment regulation intended to counter irrational tendencies may actually exacerbate the problem. ...").

380. See Murdock, supra note 17, at 210 ("One modest way to begin the process of restoring integrity to the securities markets, shake up management, and wake up gatekeepers would be for the new Congress to reinstate aiding and abetting liability in private actions.").

381. See Klock, supra note 10, at 109 ("The vehicle for attaining full disclosure is attachment of civil liability for anything less....").

382. Arthur Levitt, Chairman, SEC, The Numbers Game, Remarks to the NYU Center for Law and Business (Sept. 28, 1998) (transcript available at http://www.sec.gov/ news/speech/speecharchive/1998/spch220.txt). 
Chairman Levitt then went on to propose technical rule changes to alleviate the problem, ${ }^{383}$ which of course they did not. I suggest a simpler fix: expose those who operate in the gray area to private liability. Doing so will push gatekeepers to operate within the safe harbor of ethical behavior. ${ }^{384}$ This is the approach envisioned in the fundamental philosophy underlying our first federal securities law. ${ }^{385}$ Section 12 of the Securities Act of 1933 provides for strict liability of losses by a seller who makes a communication to an investor "which includes an untrue statement of a material fact or omits to state a material fact necessary in order to make the statements, in the light of the circumstances under which they were made, not misleading. ..."386 The term "material" is gray. ${ }^{387}$ As a consequence, sellers are incentivized to disclose anything that might in hindsight be considered material. ${ }^{388}$ This provision incentivizes sellers to act accordingly with the highest ethical standards and disclose anything that might be material rather than hiding information. ${ }^{389}$ Likewise, Rule 10b-5 contains similar broad language that provides incentives to insiders to disclose anything that might be material prior to trading. ${ }^{390}$

To restore the shaky confidence in our securities markets for the long-term, we need a similar device to incentivize accountants, auditors, bankers, credit rating agencies, underwriters, and all secondary participants in our securities markets to behave ethically. ${ }^{391}$ That device is private action liability for aiding and abetting or otherwise assisting any violation of federal securities laws. ${ }^{392}$ The recently enacted Dodd-

383. See id. ("Therefore, I am calling for immediate and coordinated action: technical rule changes by the regulators and standard setters to improve the transparency of financial statements. ...").

384. See Klock, supra note 14, at 343 (describing how private aiding and abetting liability will improve ethical standards).

385. See id. (explaining the statutory scheme of the first federal security law).

386. Securities Act of $1933 \S 12,15$ U.S.C. $\S 771$ (2006).

387. See Klock, supra note 14 , at 343 (explaining what happens when it is questionable whether an item is material).

388. See Carl W. Schneider et al., Going Public: Practice, Procedure, and Consequences, 27 VILL. L. REV. 1, 14 (1981) ("With the view toward protection against liability, there is a tendency to resolve all doubts against the company and to make things look as bleak as possible.").

389. See id. ("E]stablished underwriters and experienced counsel . . traditionally lean to a very conservative presentation, avoiding glowing adjectives and predictions.").

390. 17 C.F.R. \& 240.10b5-1 (1995).

391. See Klock, supra note 14, at 343 ("We need legislation that expressly puts unethical corporate officers and others on notice that they will be liable to victims for these risk-creating decisions.").

392. See id. at 353 ("The remedy is simple-provide a private cause of action for aiding and abetting violations of $\S 10(\mathrm{~b})$. Such regulation provides market-based incentives for ethical conduct. ...") (emphasis added). 
Frank bill ${ }^{393}$ does not do this and is an extreme disappointment considering that better results could have been obtained at lower costs by simply legislating private action liability exposure for aiding and abetting fraud. The only reasonable inference that can be drawn from this is that our political leaders are not against fraud. ${ }^{394}$

\section{CONCLUSION}

Following the Great Depression, Congress decided to federalize securities regulation. ${ }^{395}$ The legislation was intended to serve a broad remedial purpose-to provide relief for defrauded investors and to protect the integrity of the market. ${ }^{396}$ At that point in time, common law fraud doctrine held knowing participants in a fraud jointly liable. ${ }^{397}$ Congress clearly intended to provide remedies that expanded on the common law of the time, and indeed, sought to give the SEC broad powers. $^{398}$

The original philosophy of the federal securities was merely antifraud, incentivizing market participants to provide full and fair disclosure by making them criminally and civilly liable for material misstatement and omissions, and deceptive practices. ${ }^{399}$ This experiment worked well for decades. ${ }^{400}$ Financial markets grew enormously. ${ }^{401}$ Over time, the

393. Dodd-Frank Wall Street Reform and Consumer Protection Act, Pub. L. No. 111203, 124 Stat. $1376(2010)$.

394. See Prentice, supra note 6, at 682 ("The Stoneridge holding indicates that, no, some of us are not against fraud anymore."); Murdock, supra note 17, at 134-35 (arguing that courts and legislators are willing to permit fraud because they have a bias in favor of management).

395. COX ET AL., supra note 371 , at 3.

396. See, e.g., Ernst \& Ernst v. Hochfelder, 425 U.S. 185, 195 (1976). The Court noted:

The Securities Act of $1933 \ldots$ was designed to provide investors with full disclosure of material information concerning public offerings of securities in commerce, to protect investors against fraud and, through the imposition of specified civil liabilities, to promote ethical standards of honesty and fair dealing. ... The 1934 Act was intended principally to protect investors against Id. manipulation of stock prices through regulation of transactions. ...

397. Prentice, supra note 6, at 622.

398. See id. at 628 ("Congress enacted Section 10(b) for the purpose of strengthening investor protection. ..."); Steve Thel, The Original Conception of Section 10(b) of the Securities Exchange Act, 42 StAN. L. REv. 385, 392 (1990) ("One plain-language reading of section 10(b) gives the Commission broad power to regulate any practice that contributes to disorder in the securities markets or that displays speculative sentiment.").

399. See STENBERG, supra note 11, at 1 ("Undoubtedly, the central focus of the securities laws is that of disclosure, thereby providing shareholders and the marketplace with sufficient information to make relevant decisions and to be apprised of significant developments.").

400. See Klock, supra note 14, at 351 ("The concept of full and fair disclosure has served the market well."). 
law came to distinguish between different types of participants in fraud, those who were primarily liable and those who were secondarily liable. ${ }^{402}$ However, the doctrine of aiding and abetting fraud liability continued to provide relief for defrauded investors and also provide some incentives for ethical behavior by lawyers, accountants, auditors, bankers, and others working in the financial sector. ${ }^{403}$

Unfortunately, the Supreme Court declared that secondary participants cannot be held liable in Central Bank. ${ }^{404}$ This greatly reduced incentives to behave ethically and the result was an increase in the size and number of financial scandals. ${ }^{405}$ The Supreme Court greatly exacerbated the problem in Stoneridge by construing secondary participation broadly and primary participation narrowly so that fraud in the market for goods and services which affects the market's valuation of securities is deemed too remote of a factor to attach liability. ${ }^{406}$ Financial market participants in fraud are immunized from private action liability under federal securities laws as long as they do not sell or communicate directly with investors. ${ }^{407}$

Meanwhile, the Madoff scandal has publicly exposed the SEC as lacking the resources, incentives, and competence to adequately protect investors and police fraud in the securities markets. ${ }^{408}$ Although 2010 was a good year for the stock market compared with the previous two,

401. Cf. Klock, supra note 214, at 186 ("Our philosophy of letting people make their own choices, absent fraud and without judging those choices, has served our ... economic prosperity well.").

402. See Prentice, supra note 6, at 645 ("The distinction between primary and secondary liability ... largely came into existence in $1966 . .$. .).

403. Cf. Edward Labaton, Consequences, Intended and Unintended, of Securities Law Reform, 29 STETSON L. REV. 395, 411-12 (1999) ("Why was aiding and abetting liability important? ... [T] hese secondary actors often have been accurately characterized as the gatekeepers of our securities markets.... Many, perhaps most, securities frauds cannot be accomplished without the participation or inaction of these professionals.").

404. Cent. Bank of Denver, N.A. v. First Interstate Bank of Denver, N.A., 511 U.S. 164,191 (1994).

405. See Coffee, supra note 9, at 288-90 (attributing a marked decline in securities class actions against accountants, corporate counsel, and underwriters to legal changes including the elimination of aiding and abetting liability).

406. See Klock, supra note 14, at 333 (suggesting that the Court construed primary liability narrowly in order to address the question of secondary liability for vendors).

407. See Sinai, supra note 60 , at 187 ("[A] professional can rest easy so long as the attorney, CPA, and investment banker make no statements to the public. It appears no matter their culpability, they will escape private civil liability under $\S 10(b) . ")$.

408. See Klock, supra note 4, at 784 (" $[T]$ he Barney Fife caricature aptly portrays the personnel in the SEC's Office of Compliance Inspections and Examinations."); Rhee, supra note 4, at 380 ("The SEC's mishandling of the Madoff investigation is indefensible."). 
the market is still well below its high in $2007 .^{409}$ Now is the time to act. Words are meaningless without action. ${ }^{410}$ If the members of Congress are truly against fraud, they must signal so by introducing and voting for legislation that restores private action liability for aiding and abetting fraud.

409. On January 13, 2011 the Dow was less than $79 \%$ of its all-time closing high on October 12, 2007. See YAHOO! FINANCE, http://finance.yahoo.com/q/hp?s=^DJI+ Historical+Prices (last visited Sept. 29, 2011).

410. See Joseph E. Stiglitz, Information and the Change in the Paradigm in Economics, 92 AM. ECON. REv. 460, 471 (2002) ("Talk is cheap."). 
$* * *$ 